\title{
The tectonic significance of the Cabo Frio Tectonic Domain in the SE Brazilian margin: a Paleoproterozoic through Cretaceous saga of a reworked continental margin

\author{
O significado tectônico do Domínio Tectônico do Cabo Frio na
} margem Sudeste brasileira: a saga de uma margem continental retrabalhada do Paleoproterozoico ao Cretáceo

\author{
Renata da Silva Schmitt ${ }^{1 *}$, Rudolph Trouw ${ }^{1}$, William Randall Van Schmus ${ }^{2}$, \\ Richard Armstrong ${ }^{3}$, Natasha S. Gomes Stanton ${ }^{4}$
}

\begin{abstract}
The Cabo Frio Tectonic Domain is composed of a Paleoproterozoic basement tectonically interleaved with Neoproterozoic supracrustal rocks (Buzios-Palmital successions). It is in contact with the Neoproterozoic-Cambrian Ribeira Orogen along the SE Brazilian coast. The basement was part of at least three continental margins: (a) $1.97 \mathrm{Ga}$; (b) $0.59-0.53 \mathrm{Ga}$; (c) $0.14 \mathrm{Ga}$ to today. It consists of continental magmatic arc rocks of 1.99 to $1.94 \mathrm{Ga}$. Zircon cores show a $2.5-2.6 \mathrm{Ga}$ inheritance from the ancient margin of the Congo Craton. During the Ediacaran, this domain was thinned and intruded by tholeiitic mafic dykes during the development of an oceanic basin at ca. 0.59 Ma. After the tectonic inversion, these basin deposits reached high P-T metamorphic conditions, by subduction of the oceanic lithosphere, and were later exhumed as nappes over the basement. The Cabo Frio Tectonic Domain collided with the arc domain of the Ribeira Orogen at ca. $0.54 \mathrm{Ga}$. It is not an exotic block, but the eastern transition between this orogen and the Congo Craton. Almost 400 m.y. later, the South Atlantic rift zone followed roughly this suture, not coincidently. It shows how the Cabo Frio Tectonic Domain was reactivated as a continental margin in successive extensional and convergent events through geological time.
\end{abstract}

KEYWORDS: Ribeira Orogen; sutures; Orosirian; Cambrian; South Atlantic.

\begin{abstract}
RESUMO: O Dominio Tectônico do Cabo Frio é formado essencialmente por um embasamento paleoproterozoico tectonicamente intercalado com rochas supracrustais do Neoproterozoico (Sucessóes Buzios e Palmital). Está em contato com o orógeno neoproterozoico-cambriano Ribeira na costa SE do Brazil. O embasamento já fez parte de pelo menos três margens continentais: (a) a 1,97 Gaj (b) de 0,59 a 0,53 Ga; (c) de 0,14 Ga até hoje. É constituido por um complexo ortognáissico, formado em um arco magmático continental, com idade entre 1,99 e 1,94 Ga. Núcleos de zircão herdado de 2,5-2,6 Ga mostram uma herança da antiga margem continental do Craton do Congo. No final do Neoproterozoico, o Dominio Tectônico do Cabo Frio foi afinado e intrudido por diques máficos toleiticos durante a formação da bacia oceânica Buzios a ca. 0,59 Ga. Durante uma inversão tectônica para um ambiente convergente, as rochas supracrustais, depositadas nesta regiāo de transiçäo entre crosta oceânica e continental, atingiram condiçóes metamórficas de alta P-T, em razão da subducção da litosfera oceânica, sendo exumadas como nappes sobre o embasamento em seguida. O Dominio Tectônico do Cabo Frio colidiu então com o domínio do arco magmático do Orógeno Ribeira a ca. 0,54 Ga. Portanto, não é um bloco exótico, mas a transição lateral para leste entre o Orógeno Ribeira e o Craton do Congo. Quase 400 milhóes de anos após a colisäo, a zona de rifteamento do Atlântico Sul seguiu grosseiramente essa antiga sutura. Não foi uma coincidência. É uma evidência de que o Domínio Tectônico do Cabo Frio é uma margem continental, reativada como tal em repetidos eventos extensionais e convergentes através do tempo geológico.
\end{abstract}

PALAVRAS-CHAVE: Orógeno Ribeira; suturas; Orosiriano; Cambriano; Atlântico Sul.

\footnotetext{
${ }^{1}$ Department of Geology, Institute of Geosciences, Centro de Ciências Matemáticas e da Natureza (IGEO/CCMN), Universidade Federal do Rio de Janeiro - Ilha do Fundão Rio de Janeiro (RJ), Brazil. E-mail: schmitt@geologia.ufrj.br, rajtrouw@hotmail.com

2University of Kansas, Kansas, United States of America. E-mail: rvschmus@ku.edu

${ }^{3}$ Australian National University, Canberra, Australia. E-mail: richard.armstrong@anu.edu.au

${ }^{4}$ Universidade do Estado do Rio de Janeiro - UERJ, Rio de Janeiro (RJ), Brazil. E-mail: natystanton@gmail.com

*Corresponding author.

Manuscript ID: 20150025. Received in: 08/19/2015. Approved in: 01/21/2016.
} 


\section{INTRODUCTION}

The tectonic reactivation of ancient sutures between lithospheric domains is recorded through geological time (Buiter \& Torsvik 2014). Usually, this reactivation of continental margins is due to inherited heterogeneities that control the rifting processes (Manatschal et al. 2007; Beltrando et al. 2010, 2014). Former continental margins may be later involved in a collisional event, becoming the core of an orogenic belt, according to the Wilson cycle. Subsequently, the internal parts of this orogen may turn into new continental margins due to extension.

Two distinctive features are commonly present in these recycled regions. One is the occurrence of mafic and ultramafic rocks with high-P metamorphism that are either remnants of the oceanic floor or the hyperextended sublithospheric mantle underneath the continental crust (Manatschal \& Müntener 2009). Beltrando et al. (2010) point out that ocean-continent transitions are in positions favorable to reach (ultra) high-pressure conditions, following negatively buoyant oceanic lithosphere into subduction, and then being accreted to the orogen, in response to the arrival of more buoyant continental lithosphere, resisting subduction. The second feature is the presence of basement inliers within the orogenic belts. Péron-Pinvidic \& Manatschal (2010) describe the complex architecture of the rifted continental margins where "building stones" are recognized that include crustal blocks of various sizes, often referred to as microcontinents, continental ribbons, H-blocks, extensional allochthons and outerhighs. These will remain as strong lithospheric domains within the orogeny as the convergent tectonic processes start.

We present here an example of a lithospheric domain along the Atlantic coast of Brazil that might have been part of a Paleoproterozoic, a Neoproterozoic and finally a MesoCenozoic continental margin. The Cabo Frio Tectonic Domain (CFTD) corresponds to a region on the coast of Rio de Janeiro State (Brazil) that contains atypical geological features in comparison to the adjacent units of the Brazilian continental margin (Fig. 1). Considering this and since it is largely covered by post-Jurassic sedimentary/volcanic deposits, it has been regarded by several authors as an exotic terrane (Rosier 1957, 1965; Fonseca et al. 2012; Campos Neto 2000; Heilbron et al. 2000, 2008; Schmitt et al. 2008b; Brito Neves et al. 2014). One of the main reasons is that it is the only terrane that contains a Cambrian tectonometamorphic event (Buzios Orogeny; Schmitt et al. 2004), with a contrasting evolution in comparison to the adjacent Neoproterozoic Oriental Terrane (Ribeira Orogen).

In this paper, we discuss the significance of the Cabo Frio Tectonic Domain and its tectonic evolution since the Paleoproterozoic until today, with major focus on the Neoproterozoic-Cambrian time interval. Recent field data improved the geological map and section, providing clues for a reinterpretation of the structural framework and the role of this continental lithosphere in the tectonic evolution of this part of the Gondwana collage. We present the hypothesis that this domain was repeatedly (three times at least) part of a continental margin recycled in successive divergent/convergent settings, along reworked sutures, and that there is nothing exotic about it.

\section{CABO FRIO TECTONIC DOMAIN}

\section{Previous work}

Since the 1950s, this geological domain was identified as distinct from the rest of the NE-SW-oriented Ribeira belt along the southeastern Brazilian coast (Rosier 1957, 1965). The main feature is its contrasting NW-SE to N-S structural trend, oblique to the main NE-SW trend of the Ribeira belt. Ebert (1957) and Rosier (1965) considered this a foreland region in relation to the Neoproterozoic Brasiliano Orogeny that only affected the Paraiba do Sul Valley and the Serra dos Órgãos range (in the Oriental Terrane - Fig. 2). Rosier (1965) defined the SaquaremaCabo Frio-Macaé belt suggesting that it was composed of Archean geological units. Subsequently, a Rb-Sr isochron obtained for the orthogneisses yielded a Paleoproterozoic age (Delhal et al. 1969). In addition, the identification of kyanite in the supracrustals suggested a higher pressure for the metamorphic event (Fonseca et al. 1979), contrasting in relation to the other terranes of the Ribeira Orogen that are low to medium pressure and high temperature (Leonardos Jr. \& Fyfe 1974). Considering this evidence, Fonseca et al. (1979) correlated the Cabo Frio region with the Angola-Kasai Craton (part of the Congo Craton - Fig. 1) in Angola, naming it later the Cabo Frio Craton (Fonseca et al. 1984). This hypothesis was partially confirmed with the first U-Pb TIMS age obtained in single zircon grains from the orthogneisses (considered here basement) yielding an upper intercept age of $1980 \pm 18 \mathrm{Ma}$ (Zimbres et al. 1990). These authors also presented a wholerock $\mathrm{Rb}-\mathrm{Sr}$ isochron age of $1.7 \mathrm{Ga}$, interpreting that these Paleoproterozoic granitoids were not subjected to temperatures higher than $600^{\circ} \mathrm{C}$ after crystallization. A K-Ar age of $571 \mathrm{Ma}$ in hornblende reinforced the idea that they were only partially affected by the Brasiliano-Pan African event at temperatures not higher than $535^{\circ} \mathrm{C}$.

This cratonic view was questioned when $\mathrm{T}_{\mathrm{DM}} \mathrm{Nd}$ model ages of ca. 1.7 - 1.4 Ga were obtained for the supracrustal 

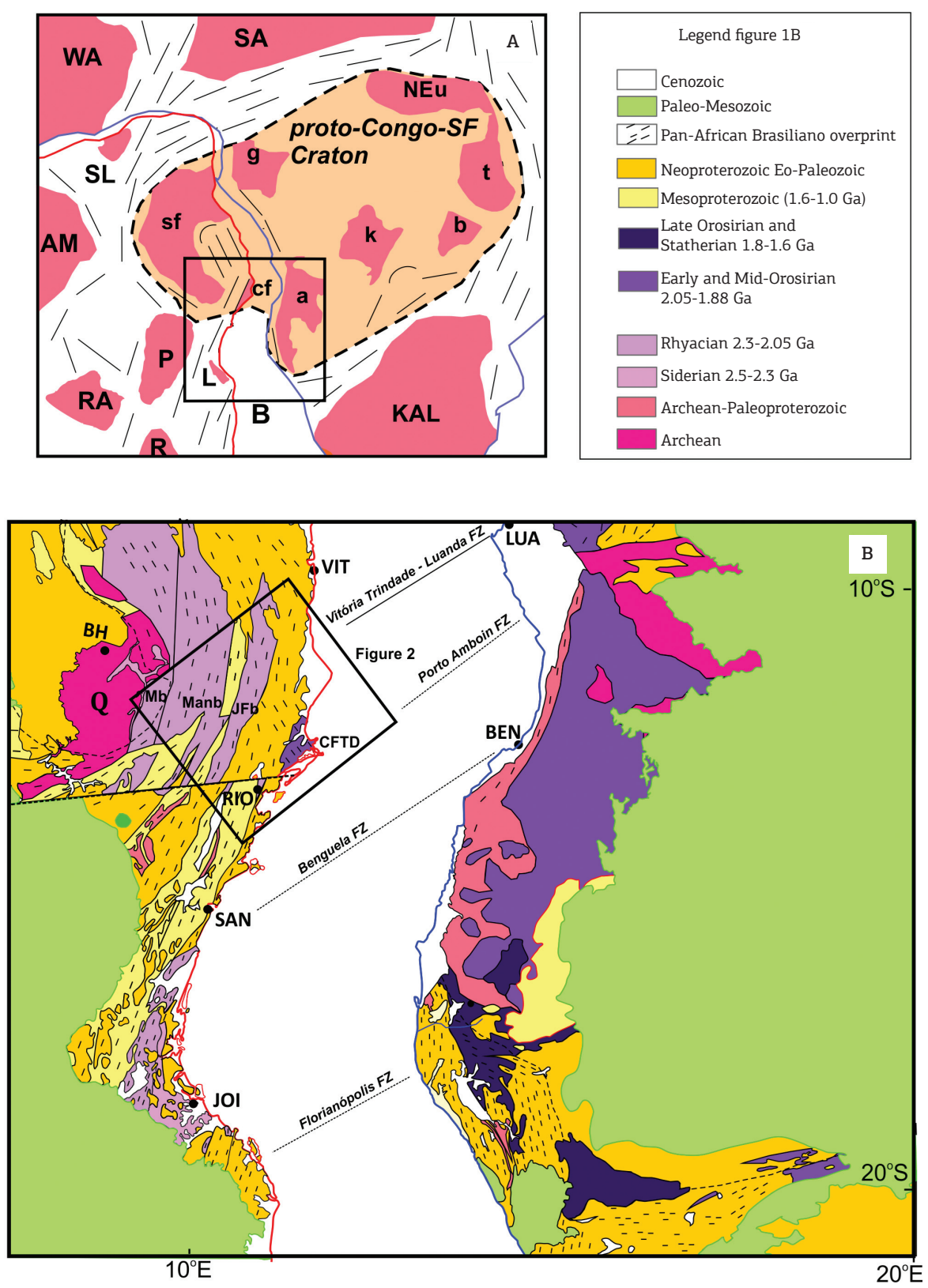

Figure 1. (A) Cabo Frio Tectonic Domain in the Gondwana context. In pink the major cratonic blocks (ArcheanPaleoproterozoic) are represented: WA - West Africa; AM - Amazon; SL - São Luis; SA - Saara; RA - Rio Apa; P -Paranapanema, R - Rio de La Plata; L - Luis Alves; KAL - Kalahari (Modified from Trompette 1994). The São Francisco-Congo craton (the area in light orange) main Archean blocks are: sf - São Francisco, g - Gabon; a - Angola; $\mathrm{K}$ - Kasai; b - Bangweulu; NEu-t - Congo-Uganda and Tanzania; cf - Cabo Frio Tectonic Domain (modified from Fernandes-Alonzo et al. 2012). Brazilian actual coastline is in red and Africa actual coastline is in blue. Figure 1B is marked by a polygon. (B) Paleogeographic configuration of Gondwana in the northern part of the South Atlantic at ca. $130 \mathrm{Ma}$ according to the Moulin et al. (2010) proposal for reconstruction, with Africa positioned to modern geographic coordinates and South America rotated. Brazilian actual coastline is in red and African actual coastline is in blue. Note the overlap of the red coastline in Rio de Janeiro region. It is related to the model of Moulin et al. (2010) as also the thick purple line that cuts the SE Brazilian territory. The domains of the Archean-Paleoproterozoic are detailed according to the periods; see legend. A - Angola block, Q - Quadrilatero Ferrifero block and adjacent Archean areas, $\mathrm{Mb}$ - Paleoproterozoic Mineiro Belt; Manb- Paleoproterozoic Mantiqueira belt; JFb - Paleoproterozoic Juiz de Fora belt. For reference some cities are marked: RIO - Rio de Janeiro; BH - Belo Horizonte; SAN - Santos; JOI - Joinville, VIT - Vitória; LUA - Luanda; BEN - Benguela. The white area between the two coastlines represents the inferred continental crust underneath the Atlantic today. Some fracture zones (FZ) are marked for reference (Benguela, Porto Amboin, Luanda, Florianópolis, from Guiraud et al. 2010). This figure was modified from Schmitt \& Armstrong (2014). 
sequences (Fonseca 1993) that are tectonically interleaved with the basement, both containing concordant ductile low-angle structures (Heilbron et al. 1982; Machado \& Demange 1990; Schmitt \& Trouw 1997; Schmitt et al. 2004, 2008a,b). Syntectonic leucossome veins in both units (basement and supracrustals) present zircon with concordant U-Pb TIMS ages of ca. $525 \mathrm{Ma}$ (Schmitt et al. 2004). This means that the CFTD geological units underwent a high temperature metamorphic event in the Cambrian. Based on these arguments, including the structural, metamorphic and lithological differences with the remaining part of the Ribeira belt, the Buzios Orogeny of Cambrian age was defined (Schmitt et al. 2004). This orogeny is considered the fourth orogenic stage in the sequence of orogenic events with related regional metamorphism and deformation recorded in the Brasiliano mobile belts of the South American platform, together with the Sierras Pampeanas Orogen (Brito Neves \& Fuck 2013).

A Cambrian to Early Ordovician tectonometamorphic event was not recognized in the adjacent Pan AfricanBrasiliano belts of both the Brazilian and African coasts, with the exceptions of the Damara Orogen in Namibia (Miller et al. 2009; Schmitt et al. 2012b) and the Paraguay belt in Brazil (Campanha et al. 2010). Consequently, the comparison and correlation with adjacent terranes was always complicated.

\section{Tectonic setting}

The CFTD is the easternmost terrane of the Ribeira Orogen, in contact with the so-called Oriental Terrane to the west, along a NE-SW oriented tectonic structure (Fig. 2). To the east, it is partially covered by the sedimentary and volcanic deposits of the Brazilian Meso-Cenozoic marginal basins. The main geological events that generated and affected the CFTD units are summarized on Table 1.

In its central portion, the Neoproterozoic-Eo-Paleozoic Ribeira Orogen is a composite of basement and arc-related terranes disposed along a NW-SE section (Heilbron et al. 2008) (Fig. 2) as follows:

1. Occidental Terrane (composed of reworked pre-Neoproterozoic basement - São Francisco Craton margin deformed with its passive margin sedimentary cover at high-grade metamorphic conditions);

2. Paraíba do Sul Domain (composed of granulitic ortho and para-derived units, tectonically overlying the Occidental Terrane; Trouw et al. 2013 consider this a part of the Brasilia Belt-further west, joining with the Embu Terrane - Fig. 1);

3. Oriental Terrane; and the

4. Cabo Frio Tectonic Domain, both described in detail below (Fig. 3).
The Oriental Terrane consists of Neoproterozoic to Ordovician magmatic intrusions and Neoproterozoic volcano sedimentary successions - equally deformed at high grade after $580 \mathrm{Ma}$ (Heilbron et al. 2013; Tupinambá et al. 2000, 2012; Valeriano et al. 2011). Its main characteristic is the absence of a basement (Fig. 2 and 3). The oldest rock is a tonalite gneiss that crystallized at ca. $790 \mathrm{Ma}$, which is considered part of an ancient juvenile magmatic arc (Heilbron \& Machado 2003). Calc-alkaline batholiths (620 - $590 \mathrm{Ma})$ are attributed to the activity of a continental arc (Rio Negro and Trajano Ortogneisses - Tupinamba et al. 2012; Fig. 3). The supracrustals are grouped into three structural domains, imbricated to the NW onto the reworked Sáo Francisco continental margin (Occidental Terrane-Figs. 2 and 3). The uppermost thrust slice is the Italva Domain (Italva Group - Fig. 3) that comprises marbles, psammitic gneisses and amphibolites of ca. $840 \mathrm{Ma}$ (Peixoto \& Heilbron 2010), and could be either interpreted as a proximal passive margin of the Oriental Terrane, or as a back-arc basin (Heilbron et al. 2013). The basal tectonic slice (Cambuci) is interpreted as a fore arc basin (Heilbron et al. 2013).

The intermediate thrust slice, the Costeiro domain, in tectonic contact with the CFTD, consists of high grade metasedimentary units, including predominantly garnetand sillimanite-rich kinzigitic gneisses, impure quartzites, banded biotite gneisses, calcsilicate rocks and amphibolites (São Fidélis Group; Tupinambá et al. 2007a; Valladares et al. 2008; Figs. 2 and 3). This sequence represents the distal portion of a passive margin of a microcontinent (Oriental Terrane or Serra do Mar Microplate) which is not interpreted as part of the São Francisco Craton (Campos Neto \& Figueiredo 1995; Heilbron \& Machado 2003).

Previous data indicate that the Oriental Terrane was accreted to the São Francisco paleocontinent margin between 606 and $540 \mathrm{Ma}$, considered the first collisional stage of the Ribeira Orogen (Tupinambá et al. 2012; Heilbron \& Machado 2003). Leucogranites and orthogneisses with ages in the range of 590 to $570 \mathrm{Ma}$ (Desengano, Anta, Cordeiro, Imbé and Rio Turvo granites; Fig. 3) and calc-alkaline orthogneisses of 560 - $540 \mathrm{Ma}$ (Serra dos Orgãos and Tingui; Fig. 3) are considered as syn-collisional igneous rocks (Silva et al. 2003; Heilbron \& Machado 2003). Different degrees of anatexis transformed the paragneisses into metatexites and/or diatexites dated at $550 \mathrm{Ma}$ by $\mathrm{U}-\mathrm{Pb}$ in zircon (Schmitt et al. 2004). Metamorphic conditions of LP-HT granulite facies are indicated by mineral parageneses in the metasedimentary rocks and patches with orthopyroxene in the syn-collisional ca. $550 \mathrm{Ma}$ augen gneisses that intrude the supracrustal association (Leonardos \& Fyfe 1974; Kühn et al. 2004). Post-collisional granites of 505 to $460 \mathrm{Ma}$ cut all other units (Valeriano et al. 2011; Fig. 3). 
The main features of the CFTD, to the SE of the Oriental Terrane, are the occurrence of a Paleoproterozoic basement and the absence of Neoproterozoic plutons (Figs. 1B, 2 and 3). The domain is characterized by two main lithostratigraphic units: Paleoproterozoic orthogneisses (basement) and high-grade Neoproterozoic volcano-sedimentary successions (Palmital and Buzios - Schmitt et al. 2004). The contact between these two units is marked by high strain shear zones. Hence, the contacts could be interpreted as sheared unconformity or, alternatively, as purely tectonic.

Therefore, the definition of the Cabo Frio Tectonic Domain must be well constrained. If we are referring to a tectonic domain formed prior to the Brasiliano events, then the Paleoproterozoic basement would solely represent the domain. If we are referring to a tectonic domain formed during the Brasiliano events, then both units should be included. Here the second possibility is assumed. Although the supracrustal units that crop out in the Oriental Terrane (neighbor terrane in the Ribeira Orogen - Figs. 2 and 3) have detrital zircon ages similar to the Palmital Succession, we still correlate them to different terranes, since they might represent distinct basins limited by a suture zone (Fernandes et al. 2015). The lithostratigraphic units of the CFTD are detailed below in items 3 and 4 .

The tectonometamorphic event that affected all units from the Cabo Frio Tectonic Domain and the eastern part

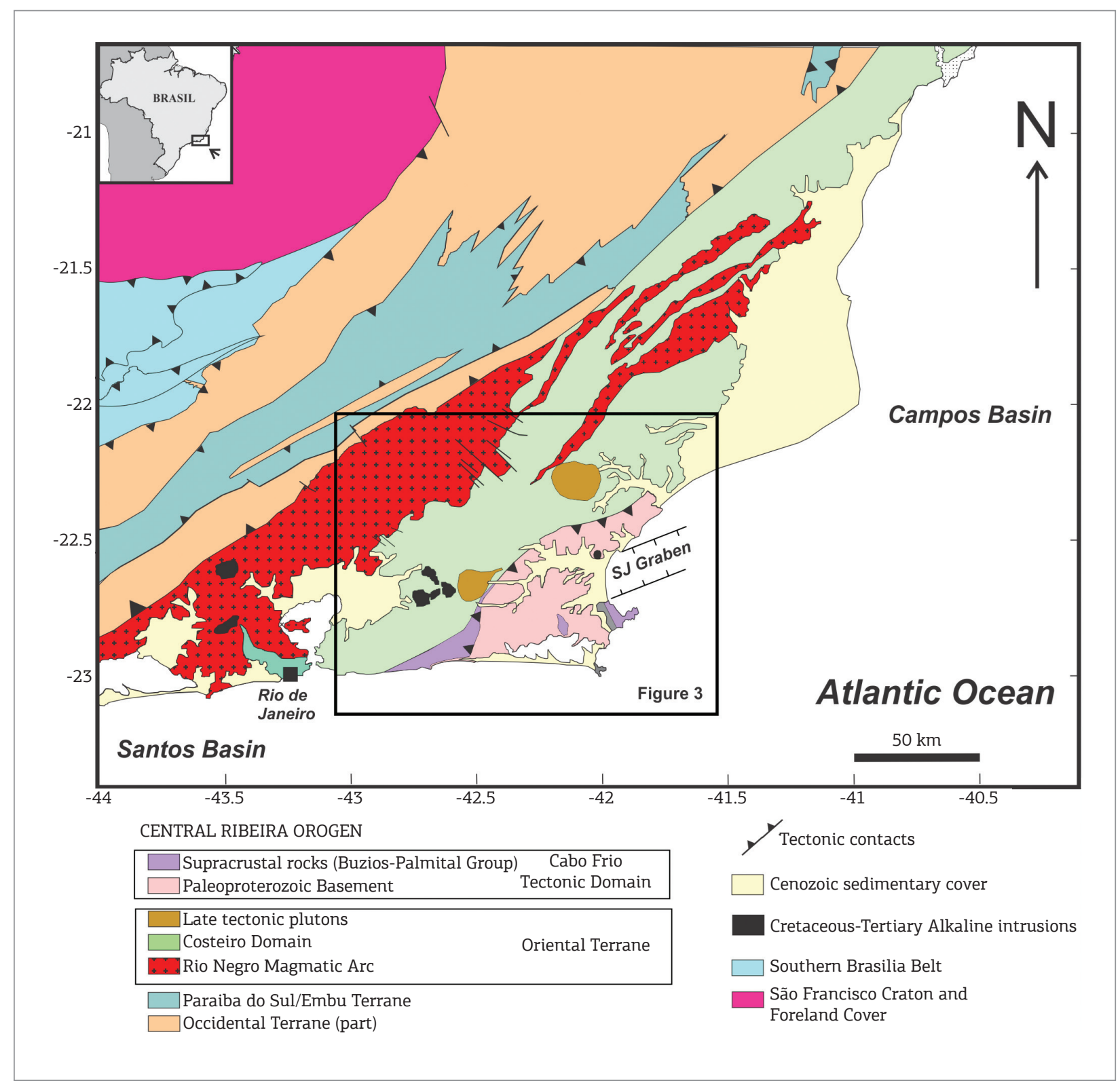

Figure 2. Tectonic setting of SE Brazil, modified from Trouw et al. (2000), Heilbron \& Machado (2003), Stanton et al. (2010). 
of the Oriental Terrane (M2 of Machado et al. 1996; Buzios Orogeny, Schmitt et al. 2004), dated at ca. $530-510 \mathrm{Ma}$, is attributed to the second collisional stage of the Ribeira Orogen between these two terranes/domains (Trouw et al. 2000). This event is also interpreted as associated to the closure of a back-arc basin of the Rio Negro Arc $(620$ - $590 \mathrm{Ma})$ located between the Oriental Terrane and the Angola craton (Heilbron \& Machado 2003). According to this interpretation, the supracrustals of the CFTD would be associated with a back-arc environment. Schmitt et al. (2008a) and Fernandes et al. (2015) considered that this basin, named Buzios-Palmital basin, was active from $590 \mathrm{Ma}$ (age of the youngest detrital zircon grain) and was subsequently deformed and metamorphosed at ca. $525 \mathrm{Ma}$ (age of metamorphic zircon) during the Buzios Orogeny. These authors also interpreted this basin as a back-arc environment with relation to the 630 Ma magmatic arc of the Oriental Terrane in the Ribeira Belt to the NW. However, after $600 \mathrm{Ma}$, the Buzios-Palmital basin evolved to an active margin setting because the arc collided with the continental margin of São Francisco (to the west- Occidental Terrane - Fig. 2, according to Heilbron \& Machado 2003) and the subduction shifted to the back-arc environment. The origin of the supracrustal units of the Oriental Terrane and the Cabo Frio Tectonic Domain may be either related to the Congo Craton margin in Africa (Schmitt et al. 2008a, Fernandes et al. 2015) or to a separate microcontinent (Campos Neto 2000; Valladares et al. 2008).

Heilbron et al. $(2008,2010)$ interpreted the CFTD as the continental platform of the Congo Craton, partially reworked by the Brasiliano events due to an eastward subduction (towards Africa), that was accreted at ca. $520 \mathrm{Ma}$ onto the Ribeira Orogen. Schmitt et al. (2008b) agreed that the CFTD has African affinities, but proposed that it was amalgamated into the Ribeira belt due to a westward subduction preceding continental collision. Campos Neto

Table 1. Main geological events that generated and affected the lithological units of the Cabo Frio Tectonic Domain prior to the Mesozoic.

\begin{tabular}{|c|c|c|}
\hline Time interval & Geological events - CFTD & Geochronological constraint - reference below* \\
\hline \multicolumn{3}{|l|}{ Paleozoic } \\
\hline $490-470 \mathrm{Ma}$ & $\begin{array}{c}\text { Intrusion of post-tectonic plutons Brittle structures: } \\
\text { Deformational phases D4-D5 }\end{array}$ & U-Pb zircon TIMS/SHRIMP ${ }^{4,7}$ \\
\hline $510-490 \mathrm{Ma}$ & $\begin{array}{l}\text { Intrusion of late-tectonic pluton (Silva Jardim) } \\
\text { Ductile structures: Deformational Phase D3 }\end{array}$ & $\begin{array}{l}\text { U-Pb zircon, monazite, sphene - TIMS - Upper } \\
\text { intercept }{ }^{4,5} \mathrm{U}-\mathrm{Pb} \text { zircon ICP-MS Laser Ablation }{ }^{8}\end{array}$ \\
\hline $530-510 \mathrm{Ma}$ & $\begin{array}{l}\text { Ductile structures: Deformational phases D1-D2 HP- } \\
\text { HT metamorphic peak - collision }\end{array}$ & U-Pb zircon, monazite - TIMS - Upper intercept ${ }^{4,6}$ \\
\hline $550-530 \mathrm{Ma}$ & $\begin{array}{l}\text { LP-HT metamorphic peak in the contact region with } \\
\text { the Oriental terrane }\end{array}$ & $\begin{array}{l}\text { U-Pb zircon/monazite TIMS and ICP-MS Laser } \\
\text { Ablation }\end{array}$ \\
\hline \multicolumn{3}{|l|}{ Neoproterozoic } \\
\hline $570-550 \mathrm{Ma}$ & Intrusion of N-MORB mafic dikes in the basement & $\begin{array}{l}\text { U-Pb zircon ICP-MS Laser Ablation/SHRIMP } \\
\text { (unpublished) }\end{array}$ \\
\hline $590-570 \mathrm{Ma}$ & Sedimentation of Palmital Succession & $\begin{array}{l}\text { U-Pb detrital zircon TIMS and ICP-MS Laser } \\
\text { Ablation }\end{array}$ \\
\hline $610-590 \mathrm{Ma}$ & $\begin{array}{l}\text { Cristallisation of volcanic/subvolcanic N-MORB } \\
\text { rocks interleaved with Buzios Succession and } \\
\text { sedimentation of Buzios Succession }\end{array}$ & $\begin{array}{l}\text { Sm-Nd isochron whole rock }{ }^{5} \mathrm{U}-\mathrm{Pb} \text { detrital zircon } \\
\text { ICP-MS Laser Ablation }{ }^{6}\end{array}$ \\
\hline \multicolumn{3}{|l|}{ Paleoproterozoic } \\
\hline $2000-1940 \mathrm{Ma}$ & $\begin{array}{c}\text { Cristallisation of calc-alkaline series of plutonic } \\
\text { rocks from the basement }\end{array}$ & $\begin{array}{c}\text { U-Pb zircon - TIMS - Upper intercept } \mathrm{t}^{3,4,5} \mathrm{U}-\mathrm{Pb} \text { zircon } \\
\text { SHRIMP }{ }^{9,10} \mathrm{Rb}-\mathrm{Sr} \text { whole } \text { rock }^{1,2}\end{array}$ \\
\hline \multicolumn{3}{|l|}{ Archean } \\
\hline $2600-2500 \mathrm{Ma}$ & $\begin{array}{l}\text { Inheritance of reworked crust (inherited zircon cores } \\
\text { in the basement) }\end{array}$ & U-Pb zircon SHRIMP ${ }^{9,10} \mathrm{~T}_{\mathrm{DM}} \mathrm{Nd}$ model ages ${ }^{2,4,8}$ \\
\hline${ }^{*}$ References & \multicolumn{2}{|c|}{$\begin{array}{l}1 \text { - Delhal et al. (1969); } 2 \text { - Fonseca (1993); } 3 \text { - Zimbres et al. (1990); } \\
4 \text { - Schmitt et al. (2004); } 5 \text { - Schmitt et al. (2008); } 6 \text { - Fernandes et al. (2015); } 7 \text { - Bongiolo et al. (2015); } \\
\text { 8 - Moraes (2009); } 9 \text { - Schmitt \& Armstrong (2014); 10- Schmitt et al., submitted }\end{array}$} \\
\hline
\end{tabular}

CFTD: Cabo Frio Tectonic Domain. 


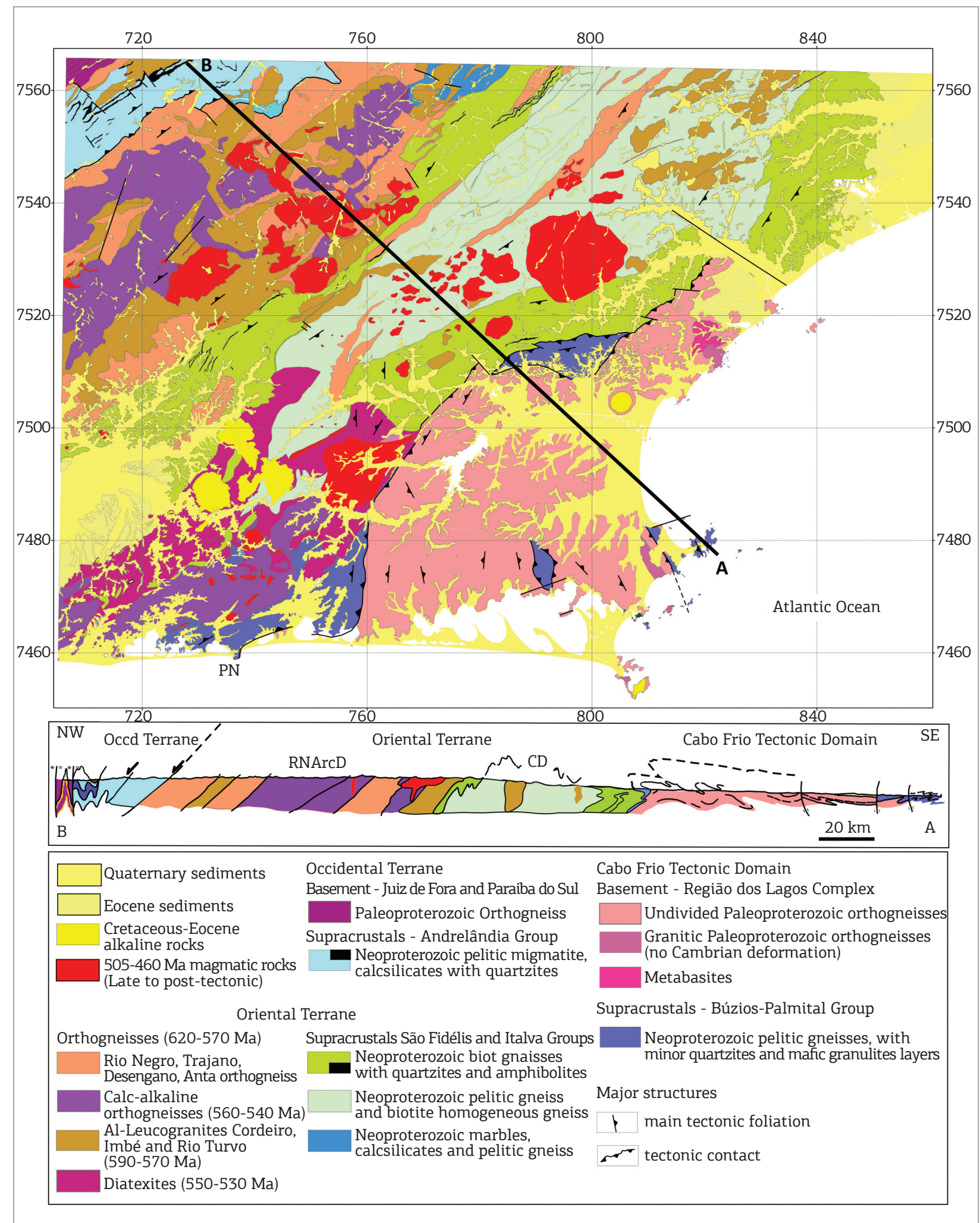

Figure 3. Detailed geological map of the Cabo Frio Tectonic Domain and part of the Oriental Terrane of the Ribeira Orogen. Modified and integrated from the 1:100.000 geological sheets of the Geological Survey of Brasil with UERJ and DRM-RJ: Schmitt et al. 2009a,b; Tupinambá et al. 2009; Geraldes et al. 2009; Almeida et al. 2009 and Peternel et al. (in prep). PN means Ponta Negra region. 
and Figueiredo (1995) described it as an exotic terrane thrusted by the Serra do Mar microplate. Valeriano et al. (2008) attributed the development of superimposed subvertical folding and steep dextral-oblique shear zones that controlled the emplacement of post collisional granites in the Ribeira Orogen to the docking of the Cabo Frio terrane. Schmitt et al. (2008b) pointed out that the occurrence of Cambrian metamorphic rocks along the present African and South American coastlines shows that Mesozoic rifting closely follows Paleozoic sutures of West Gondwana. Today, this lithospheric domain partially coincides with the Cabo Frio Structural High, which divides the Santos and Campos marginal Atlantic basins (Stanton et al. 2010).

\section{TECTONIC EVOLUTION DURING THE PALEOPROTEROZOIC}

The oldest geological unit of the CFTD is a complex of mostly granitic orthogneisses (Regiáo dos Lagos Complex - Fonseca et al. 1979). This continental crust was formed during the Orosirian and is composed of a magmatic series with calc-alkaline affinities (Fonseca 1993; Schmitt et al. 2004, 2008b; Viana et al. 2008). There are some low strain domains where the ductile deformation attributed to the later Cambrian collision is not apparent, although there is recrystallization with predominant granoblastic and granolepidoblastic texture in thin section. In these low strain domains, this unit shows no compositional gneissic layering and primary igneous structures are preserved such as cross-cutting features, magmatic foliation, enclaves and isotropic fabric (Fig. 4A,B). Three main lithological groups were recognized, based on composition and age, all with igneous protoliths. No supracrustal or igneous rocks older than the plutonic complex were described, only inherited $2.6-2.5$ Ga age zircon grains (Schmitt \& Armstrong 2014).

The oldest lithotype is a group of amphibole- and biotite-bearing quartz-dioritic and tonalitic orthogneisses with medium to coarse-grained equigranular texture. Usually, they present numerous microdioritic centimetric enclaves and a foliation marked by mafic aggregates and elongated mafic enclaves (Fig. 4A,B). This foliation is interpreted to be igneous and is cross-cut by other granitoids from the Região dos Lagos Complex (Fig. 4B).

The predominant lithotype is composed of granitic orthogneisses, varying from granodioritic to syenogranitic in composition, with subordinate quartz-monzonitic units. In spite of the vast compositional range, it is possible to distinguish two main lithotypes that show transitional contacts. The mesocratic monzogranitic to granodioritic orthogneisses are grey rocks with hornblende and biotite that cross-cut the tonalitic units and usually do not present any foliation. They show medium to coarse-grained texture and could be either equigranular or porphyritic, with microcline phenocrysts up to $7 \mathrm{~cm}$ long. Finally, isotropic fine-grained leucocratic granites cross-cut all units described above with sharp contacts (Fig. 4B).

This series of magmatic rocks crystallized between 2.0 and $1.95 \mathrm{Ga}$ (Zimbres et al. 1990; Schmitt et al. 2004, 2008b; Schmitt \& Armstrong 2014) and present $\mathrm{T}_{\mathrm{DM}} \mathrm{Nd}$ model ages varying from 2.7 to $2.4 \mathrm{Ga}$ (Fonseca 1993; Schmitt et al. 2008a). Consequently, this unit is interpreted as reworked continental crust. Schmitt and Armstrong (2014) dated 2.6 Ga zircon cores (inherited crystals) and interpreted them as belonging to one of the sources of this magmatism. All these ages are similar to the units that occur on the Angola Block (part of the Congo Craton, De Carvalho et al. 2000; De Waele et al. 2008 Fig. 1A). An Archean domain occurs in the eastern region of Angola (Africa), approximately $250 \mathrm{~km}$ from the coast, with ages of 3.2 to $2.6 \mathrm{Ga}$ (Begg et al. 2009; Fig. 1B). To the west, still in Angola, a major granitic province of Paleoproterozoic age is present and might be correlated with the CFTD rocks, since the major peak of ages is around 1.95 Ga (Delor et al. 2006; McCourt et al. 2013; Fig. 1B) (see Discussion section).

Geochemical data indicate a calc-alkaline character with medium- to high-K, predominantly metaluminous tendencies and other similarities relative to igneous suites generated in modern compressive tectonic active margin environments, particularly those from the magmatic arcs in the Chilean Andes (Fonseca 1993; Viana et al. 2008). Considering the nature of the rock association, the $\mathrm{T}_{\mathrm{DM}} \mathrm{Nd}$ model ages and the geochemical signature, we interpret this unit as a mature continental magmatic arc. The absence of any metamorphic event before the Cambrian indicates that this could have been a Paleoproterozoic accretionary margin (Schmitt \& Armstrong 2014). In addition, the lack of temporal relation between the CFTD/Angola block with the lithological units of the São Francisco Craton and its reworked margin (Mantiqueira and Juiz de Fora domains) (Avila et al. 2010; Heilbron et al. 2010; Teixeira et al. 2015) could indicate that they were separated by an ocean (Fig. 1A,B) (see "Discussion" section).

\section{TECTONIC EVOLUTION DURING THE NEOPROTEROZOIC-CAMBRIAN}

After the consolidation of the Paleoproterozoic crust, there is no record of lithological units in the CFTD during 

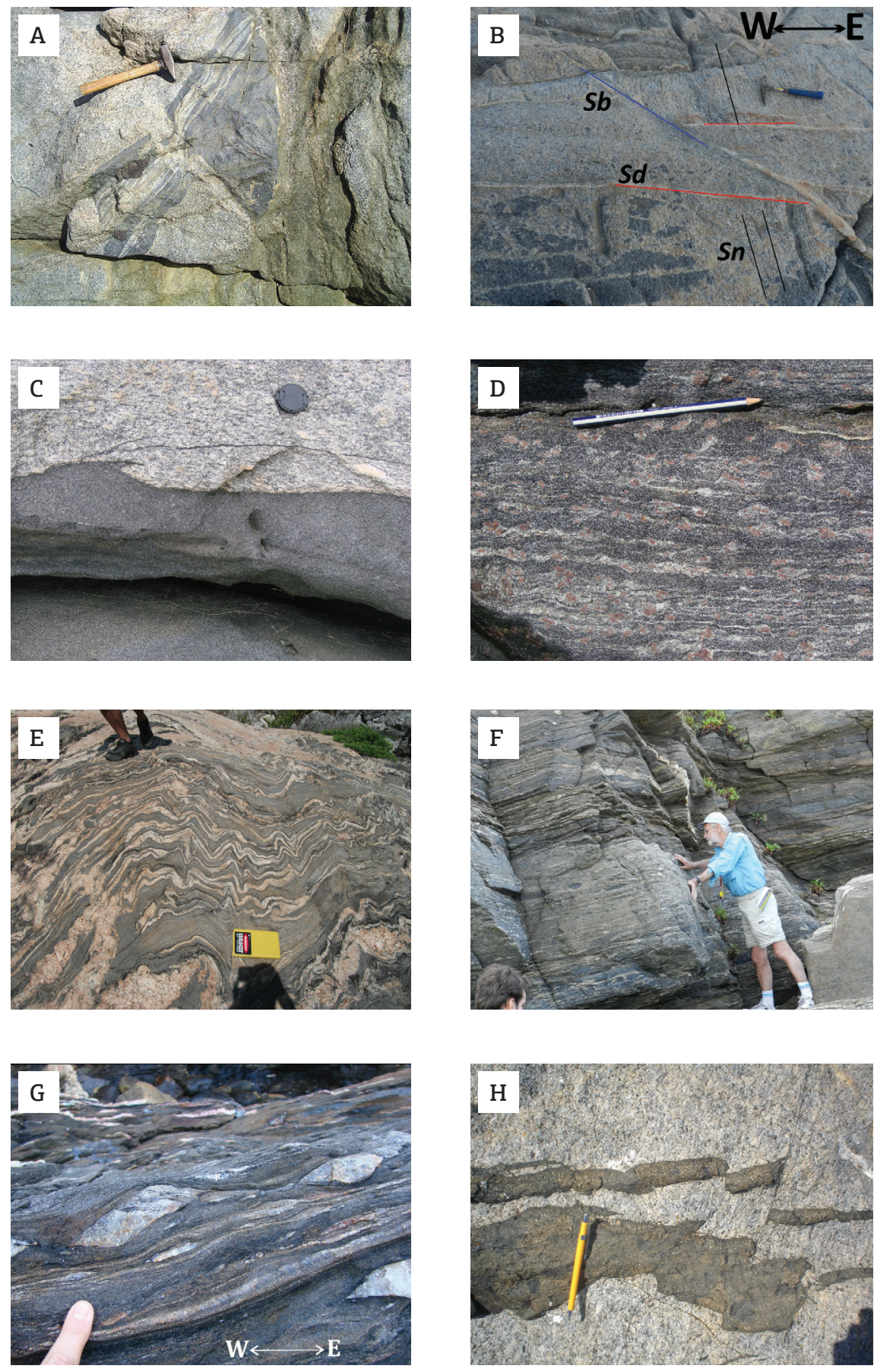

Figure 4. Photos from the Cabo Frio Tectonic Domain units. (A) $1.97 \mathrm{Ga}$ coarse grained granite with dioritic enclaves, probably coeval and related to magma mingling; (B) Cross-cutting contact between the foliated 1.98 Ga tonalitic orthogneiss ( $\mathrm{Sn}$ - black line) and the $1.95 \mathrm{Ga}$ leucocratic granitic isotropic dyke clearly cutting the former (Sd - red line). The foliation is interpreted to be igneous in origin therefore of Paleoproterozoic age. Note that the dyke is disrupted by a younger shear zone related to the Cambrian orogeny ( $\mathrm{Sb}$ - blue line); (C) Paleoproterozoic granitic orthogneiss intruded by mafic tholeiitic dykes of unknown age (now amphibolites). Both units are deformed due to the Cambrian collisional orogeny. (D) Garnet-cpx granulite deformed during the Cambrian collisional event; (E) Migmatitic paragneiss from the Palmital succession; (F) Tectonic contact between the Paleoproterozoic basement (below) and the Buzios succession, indicated by the right hand of J. Bradshaw. Note the parallel foliation and high strain zone; (G) Kinematic indicators (sigma and S-C foliation) showing top to E movement in the metasedimentary sequence of Palmital Succession at the contact with the Paleoproterozoic basement in Ponta Negra (see location on Fig. 3); (H) Cretaceous Diabase disrupted by normal faults from the South Atlantic rifting event displacing the gneiss of the CFTD. 
the Mesoproterozoic. A series of mafic N-MORB tholeiitic dykes (deformed ortho-amphibolites) cross-cut all the basement lithotypes (Schmitt et al. 2008a; Schmitt et al. 2009a,b) (Fig. 4C), but preliminary unpublished U-Pb data indicate that these dykes crystallized at ca. 590-560 Ma. They contain zircon crystals, interpreted as xenocrysts, ranging in age from Paleoproterozoic to Neoproterozoic (Schmitt \& Armstrong 2014). These mafic dykes do not cross-cut the Neoproterozoic supracrustal unit that is in tectonic contact with the basement, corroborating the hypothesis that the supracrustals are nappes emplaced later in the Cambrian. Laterally they might be related, since they are contemporaneous with the volcano-sedimentary protoliths of the supracrustal unit.

The supracrustal unit was deposited only at the end of the Neoproterozoic, with a maximum depositional age of $570 \mathrm{Ma}$ (Fig. 4F; Schmitt et al. 2004; Fernandes et al. 2015). This unit (Fig. 3) includes mafic gneiss and paragneisses with a maximum exposed thickness of $500 \mathrm{~m}$. Four compositional lithofacies were recognized: aluminous rocks containing kyanite and/or sillimanite, calc-silicate rocks, quartz-feldspar rocks and metabasites (Schmitt et al. 2008a). Based on relative proportions of these lithofacies, two sucessions were defined: the Buzios and the Palmital successions.

The Buzios Succession is mainly composed of pelitic paragneisses containing sillimanite-kyanite-garnet-biotite; they are banded or homogeneous, leucocratic to mesocratic, with intercalations of up to $50 \mathrm{~m}$ thick of calc-silicate and mafic to ultramafic layers (amphibolites and cpx-gneisses). Minor up to $5 \mathrm{~cm}$ quartzitic layers occur locally. The sediments are interpreted as deposited in a hemipelagic environment (Schmitt et al. 2008a). The metabasites occur as single layers of a few centimeters to meters in thickness finelly interbedded with the aluminous metasedimentary and calcsilicate rocks, or as more homogeneous packages up to $40 \mathrm{~m}$ thick. The mineralogical content is heterogeneous and the lithotypes vary from garnet amphibolite, diopside amphibolite, diopside-garnet amphibolite, garnet-metaclinopyroxenite to massive amphibolite. According to whole-rock major and trace, including rare earth element distributions in the mafic-ultramafic intercalations, their protoliths are interpreted as subalkaline basalt/gabbro of tholeiitic affinity with E-MORB signature from a non-subduction environment (Fig. 4D) (Schmitt et al. 2008a). These mafic rocks have positive $\varepsilon N d(t)$ and $\mathrm{T}_{\mathrm{DM}} \mathrm{Nd}$ model ages of $1.1 \mathrm{Ga}$. Schmitt et al. (2009b) analysed samples from thicker homogeneous layers of these mafic rocks (up to $40 \mathrm{~m}$ thick). These layers presented a REE-flat distribution, similar to $\mathrm{N}-\mathrm{MORB}$ signature, and plotted in the Hf/3xThxTa tectonic diagram in both N-MORB and Island Arc Basalts fields (Wood 1980). Schmitt et al. (2008a) discussed that the few centimeters thick layers of mafic rocks were in association with the siliciclastic deposits and represent a volcano-sedimentary package, partially explaining why these have E-MORB affinities (see upper sequence of Fig. 4F). The thicker mafic layers could be either lava flows of sills with N-MORB affinities of ca. $606 \mathrm{Ma}$ (Sm-Nd WR isochron - Schmitt et al. 2008a).

In addition, new $\mathrm{U}-\mathrm{Pb}$ data combined with $\mathrm{Lu}-\mathrm{Hf}$ data on detrital zircons (Fernandes et al. 2015) show that the Buzios succession have a major population of detrital Neoproterozoic zircon grains with positive $\varepsilon \mathrm{Hf}(\mathrm{t})$. This juvenile contribution in the Buzios succession indicates that the source could be either related to a rift event or an intraoceanic magmatic arc in distal zones of the Ribeira Orogen. In conclusion, the hypothesis that the Buzios succession is deposited in an ocean floor environment, distal from a continental margin and interleaved with contemporaneous volcanic deposits is supported by all this evidence.

The Palmital Succession is mainly composed of leuco- to mesocratic (garnet)-sillimanite-biotite paragneisses $(>300 \mathrm{~m}$ ), with intercalations of feldspar-bearing quartzite layers $(>3 \mathrm{~m}$ of thickness) and greenish calcsilicate layers (grt-cpx gneiss) up to $20 \mathrm{~m}$ thick (Schmitt $e$ al. 2004). This succession is interpreted as immature turbidites from submarine fans on a continental slope, and presents no mafic volcanic/plutonic rocks. $\mathrm{T}_{\mathrm{DM}} \mathrm{Nd}$ model ages for the sedimentary protoliths are ca. $1.7 \mathrm{Ga}$ (Schmitt et al. 2008a). U-Pb detrital zircon data show a major population of ca. $750-570 \mathrm{Ma}$, but zircon grains present negative $\varepsilon \mathrm{Hf}(\mathrm{t})$, contrary to the Buzios succession (Fernandes et al. 2015). These authors concluded that the Palmital succession has a major contribution from the arc domain of the Ribeira Orogen (Fig. 2) and its maximum depositional age was ca. $570 \mathrm{Ma}$.

Therefore, Fernandes et al. (2015) proposed that Buzios and Palmital successions formed in distinct tectonic environments and time periods. The Buzios Basin, developed at ca. $600 \mathrm{Ma}$, in an extensional setting and could either be a back-arc basin or represent an oceanic realm. The Palmital succession deposited in a convergent setting at ca. 590 - $550 \mathrm{Ma}$, as a fore arc deposit, that culminated with a continental collision (Buzios orogeny). Both successions present a minor detrital zircon contribution from the Paleoproterozoic basement, suggesting that the Angola continental margin was close to this convergent setting, in agreement with the age of ca. $540 \mathrm{Ma}$ considered as the initiation of collision.

\section{Buzios orogeny}

The CFTD shows tectonic and inverted contacts between these two contrasting units: the basement (a Paleoproterozoic continental crust) and the supracrustals (sedimentary/ 
volcanic successions from a deep sea environment) (Fig. 4F). Although the units close to the contact always show high strain structures and partial melting (Fig. 4E, F), the contacts could be alternatively interpreted as unconformities (Fonseca et al. 1984). But there are two points that make this interpretation dubious: (a) metamorphic grade and (b) primary tectonic setting. The Buzios-Palmital successions are allochthonous to the basement and came from more distal parts of a continental margin and also deeper parts of the lithosphere.

The driving force for this tectonic inversion is the metamorphic and deformational evolution that affected these units related to the late Brasiliano tectonic events. The tectonic foliation and lineation in the basement and cover are parallel along their contacts (Fig. 4F). The supracrustals show a main foliation $\left(S_{1+2}\right)$ with isoclinal intrafolial folds parallel to the sedimentary contacts ( $\mathrm{S} 0$ - primary foliation). The stretching and mineral lineations are NW-SE and N-S oriented. The development of this main foliation $\left(S_{1+2}\right)$ was coeval with the high grade metamorphic event. This is shown by the stromatic texture of the pelitic layers and also by inclusion trails in syn-kinematic garnets (Heilbron et al. 1982).

The attitude of the main foliation $\left(S_{1+2}\right)$ is variable due to the mega scale folding that is related to $\mathrm{D}_{3}$ deformational phase in the CFTD. The $S_{3}$ foliation is a localized spaced cleavage parallel to the axial surfaces of $\mathrm{F}_{3}$ folds, which in turn are recumbent with gently inclined axial planes and subhorizontal axes trending from N-S to NW-SE (see geological cross section of Fig. 3). During $\mathrm{D}_{3}$ deformation, the metamorphic conditions were at lower $P$ and $T$ on a clockwise retrograde path, mainly related to decompression, as shown by the partial replacement of kyanite by sillimanite crystals, parallel to $\mathrm{L}_{3}$, and folding of the leucosomes by $\mathrm{F}_{3}$ folds (Schmitt et al. 2004).

The strain distribution in the basement is strongly partitioned. Along the contacts with the supracrustals, migmatization is apparent and high grade shear zones are present (Fig. 4F). Away from the contacts, the strain exhibits only localized meter-scale NW-SE shear zones (Fig. 4B). A pervasive NNW-SSE subhorizontal stretching lineation of quartz and feldspar is well developed with few kinematic indicators showing both top-to-NW and top to-SE tectonic transport.

This main structural framework of the CFTD changes along the western contact with the Oriental Terrane (Fig. 3). Along this contact, the units are deformed by folds with NE-SW oriented axes, plunging ca. $40^{\circ}$ to $S W$ with axial surfaces dipping in the same direction (Fig. 3 - geological cross section). These megascale reclined folds could be attributed to a $\mathrm{D}_{4}$ deformational phase or could still be related to $\mathrm{D}_{3}$.
An E-W shallow-plunging quartz stretching lineation with top to $\mathrm{E}$ kinematic indicators is present along this contact (Fig. 4G). This late-lineation is parallel to a fibrolitic sillimanite lineation that occurs on $S_{3}$ foliation in the eastern part of the CFTD and shows both top to $\mathrm{W}$ and $\mathrm{E}$ tectonic transport. It is noteworthy that this sillimanite lineation also occurs on partially substituted remnant kyanite crystals (Schmitt et al. 2004).

The metamorphic grade of the basement and supracrustals is apparently compatible. The latter is characterized by medium to high pressure granulites. Pelitic protoliths show the paragenesis of $\mathrm{Ky}+\mathrm{K}$-feldspar in the presence of melt and absence of muscovite (Fig. 4E). Mafic volcanic layers present cpx+garnet+plagioclase+quartz (Fig. 4D), coherent with the metamorphic grade of the pelitic metasedimentary rocks. This association is registered in the Buzios Succession. In the Palmital Succession, sillimanite is the stable aluminosilicate, indicating a higher temperature and/or lower pressure. Basement rocks do not present a diagnostic paragenesis, but the textures such as granoblastic, antiperthite and symplectites are consistent with high grade metamorphism. The localized partial melt veins are also coherent with this interpretation. Pervasive migmatization of the basement rocks occurs only in high strain domains. Overgrowth of metamorphic rims on the Paleoproterozoic zircon grains takes place only in localized shear zones, probably triggered by fluids. The localization of deformation and metamorphism within the basement and some geochronological data might suggest that this older unit did not experience the high pressure of the supracrustals.

The deformation and high grade metamorphism responsible for the tectonic inversion of the sedimentary basin is attributed to an orogenic event of Cambrian age. Schmitt et al. (2004, 2008b) dated the $\mathrm{D}_{1+2}$ syntectonic leucosome from both basement and supracrustals, and defined a ca. $530 \mathrm{Ma}$ tectonometamorphic event related to a convergent margin that culminated with a continental collision (Buzios Orogeny). This partial melt product was generated during the metamorphic peak $\left(\mathrm{D}_{1+2}\right)$ and was folded by the megascale $\mathrm{F}_{3}$-folds (Fig. 4E).

In the basement, the lower intercepts of the U-Pb discordia lines are in the interval between 600 and $450 \mathrm{Ma}$, consistent with this event (Schmitt et al. 2004, 2008b). The metamorphic rims of the Paleoproterozoic zircon grains in the shear zones are dated at ca. $505 \mathrm{Ma}$ (Schmitt et al. 2008b). In the supracrustals, all metamorphic minerals are formed during the Cambrian (ca. $530 \mathrm{Ma})$. Zircon, monazite, sphene and rutile were dated and yielded a metamorphic time interval between 525 and $510 \mathrm{Ma}$ for the eastern CFTD and 505 - $490 \mathrm{Ma}$ for the western CFTD (Schmitt et al. 2004). The occurrence of a late $\mathrm{F}_{4}$-reclined 
megascale fold in the western region could partially explain this (Fig. 3). These younger ages could indicate that units in this region stayed deeper in the crust and the $\mathrm{D}_{4}$ deformational phase would bring them up later. The cooling rate calculated for the eastern part of CFTD is rapid until ca. $510 \mathrm{Ma}$ (more than $20^{\circ} \mathrm{C} / \mathrm{Ma}$ ), and after this diminishes to $5-10^{\circ} \mathrm{C} / \mathrm{Ma}$ (Schmitt et al., 2004).

In the adjacent Oriental Terrane (Figs. 2 and 3), there are also metamorphic ages of ca. $550-510 \mathrm{Ma}$ (Schmitt et al. 2004, 2012a; Fernandes et al. 2015). Furthermore, a series of plutons with ages from 510 to $480 \mathrm{Ma}$ intrude this terrane and are interpreted as post-tectonic (Valeriano et al. 2011). Though one of these plutons cross-cut the CFTD in its NW tip, the Silva Jardim Pluton, dated at $505 \mathrm{Ma}$ (Figs. 2 and 3) (Moraes 2009). This pluton presents an oriented igneous foliation and is considered a late-collisional magmatic body (Moraes 2009). The youngest magmatic intrusions registered in the CFTD during the Paleozoic are post tectonic pegmatites and granites of ca. $440 \mathrm{Ma}$ dated with U-Pb in zircon (Schmitt et al. 2004, Bongiolo et al. 2015).

\section{TECTONIC EVOLUTION DURING THE MESO-CENOZOIC}

The CFTD is today partially exposed on the Brazilian Continental margin. It presents magmatic and sedimentary units related to a major extensional event that started in the Lower Cretaceous (Rabinowitz \& La Brecque 1979; Meisling et al. 2001; Moulin et al. 2010; Oliveira et al. submitted) and culminated with the Gondwana rifting and the opening of the South Atlantic. During the continental rifting, widespread tholeiitic basalt magmatism affected the CFTD and the Ribeira Belt in the form of mafic dykes, mainly NE-SW oriented, creating the Serra do Mar Dyke Swarm (SMDS), of Early Cretaceous age (148 - $132 \mathrm{Ma}$; Turner et al. 1994; Guedes et al. 2005) (Fig. 4H). Several rifting structures, such as normal faults and fracture systems, are observed in close association with the dykes along the CFTD (Tetzner et al. 2001; Almeida et al. 2013) (Fig. 4H). The main strike direction is NE-SW, coincident with that of the magmatic bodies previously mentioned, with a secondary NW-SE system mainly observed at the Buzios region, where it shows cross-cutting relationships with the dykes, indicating both previous activity and reactivation during the rifting phase. Valente et al. (2007) showed that two distinct suites of dykes occur: a low-Ti diabase system, that intrudes only the CFTD, and a high-Ti diabase system that intrude the rest of the Ribeira Orogen. The authors propose that it could be either related to the different nature of the lithospheric mantle underneath the CFTD or to differential lithospheric thickness prior to rifting.

Later, a post-rift regional extensional event reactivated the Precambrian basement during the Neocretaceous/Cenozoic, culminating with the formation of the Southeast Cenozoic Rift System (Ricomini et al. 2004; Zalán \& Oliveira 2005), characterized by several near-coast ENE oriented horsts and grabens, which are systematically segmented by NW-SE transfer faults. This system includes the Barra de São João Graben (Mohriak et al. 1990) which affected the CFTD basement and is located adjacent to its coast offshore (Fig. 2), forming also the ENE to E-W regional fault systems, like the Pai Vitório and Araruama Fault systems (Souza 2011). These fault systems clearly cross-cut the tholeiitic dykes (Stanton et al. 2005). In addition, a series of Cenozoic alkaline plugs is present, commonly related to a thermal anomaly under the continental lithosphere that generated an approximate $\mathrm{WNW}$ to $\mathrm{E}-\mathrm{W}$ magmatic trend irregularly younging towards the CFTD (Thomaz-Filho et al. 2000). These magmatic rocks vary in age from 100 to ca. $50 \mathrm{Ma}$ and are also cross-cut by the Araruama Fault System (Geraldes et al. 2013; Souza 2011).

\section{DISCUSSION}

\section{Geochronological barcode of the Cabo Frio Tectonic Domain}

The CFTD presents a unique geochronological barcode, with similar evolution identified only in the basement that crops out along the Angolan coast (Fig. 1B). Several geochronological data were obtained in this tectonic domain with K-Ar, Ar-Ar, Rb-Sr, U-Pb, Sm-Nd and Lu-Hf methods, summarized in Appendix I.

The oldest ages of $2.55 \mathrm{Ga}$ are preserved in cores of inherited zircon grains from the ca. 1.95 Ga granitoids, matching the age of the Archean crust that crops out in the eastern basement of Angola (Schmitt \& Armstrong 2014) (Fig. 1). These also coincide with the $\mathrm{T}_{\mathrm{DM}} \mathrm{Nd}$ model ages from the Orosirian Basement (Fig. 5). But, since these model ages are average ages of mixed sources, there can be contributions from both an Archean source and an Early Paleoproterozoic source. This Archean inheritance is also present in a discrete population of detrital zircon within the supracrustal rocks associated with the CFTD (Fig. 5A,B).

In the CFTD, Early to Mid-Orosirian ages represent the major event of continental crust reworking and the generation of a series of calc-alkaline magmas that constitute the basement (Fig. 5A,B). Within the supracrustals there is a population of detrital zircon indicating that this magmatic 
province could be one of the sources, but not the main contributor (Fig. 5A,B). Some $\mathrm{T}_{\mathrm{DM}} \mathrm{Nd}$ model ages from the supracrustals define a field of this age (Fig. 5B), but these are mixing ages between Archean and Post-Orosirian sources. The more abundant $\mathrm{T}_{\mathrm{DM}} \mathrm{Nd}$ model ages of the supracrustals are around $1.75 \mathrm{Ga}$, which probably could represent a mix of Orosirian and post-1.5 Ga sources.

Up to now, there is no Precambrian plutonic rock younger than $1.95 \mathrm{Ga}$ documented in the CFTD. To the south of the Angola block, in Africa, a major piece of Staterian continental crust (ca.1.8 Ga) is documented, which continues into Namibia representing the southwestern corner of the Congo Craton (Kröner et al. 2010) (Fig. 1B). Within the CFTD supracrustals there is a major gap of sources for detrital zircon between 1.9 and $1.3 \mathrm{Ga}$ (Fig. 5B). Although there is an important Mesoproterozoic magmatic province (Kunene Complex- De Waele et al., 2008; Seth et al., 2003) in the southern part of Angola and northern Namibia, it did not contribute to the CFTD supracrustal basin (Fig. 1).

The second major detrital zircon population in the paragneisses of the CFTD defines a ca. 1.05 Ga peak (Fernandes et al., 2015)(Fig. 5A,B). This time period, at the end of the Mesoproterozoic and beginning of the Neoproterozoic, is characterized by extensional events in the São Francisco and Congo cratons (Tupinambá et al. 2007b). Several alkaline rocks are documented and interpreted as syn-rift intrusions (Silva et al. 2008; Pedrosa Soares \& Alkmim 2011). $\mathrm{T}_{\mathrm{DM}} \mathrm{Nd}$ model ages of ca. 1.0 Ga were obtained in the mafic layers of volcanic origin intercalated within the sedimentary Buzios Succession (Schmitt et al. 2008a). This represents a mixture of older sources with Neoproterozoic sources.

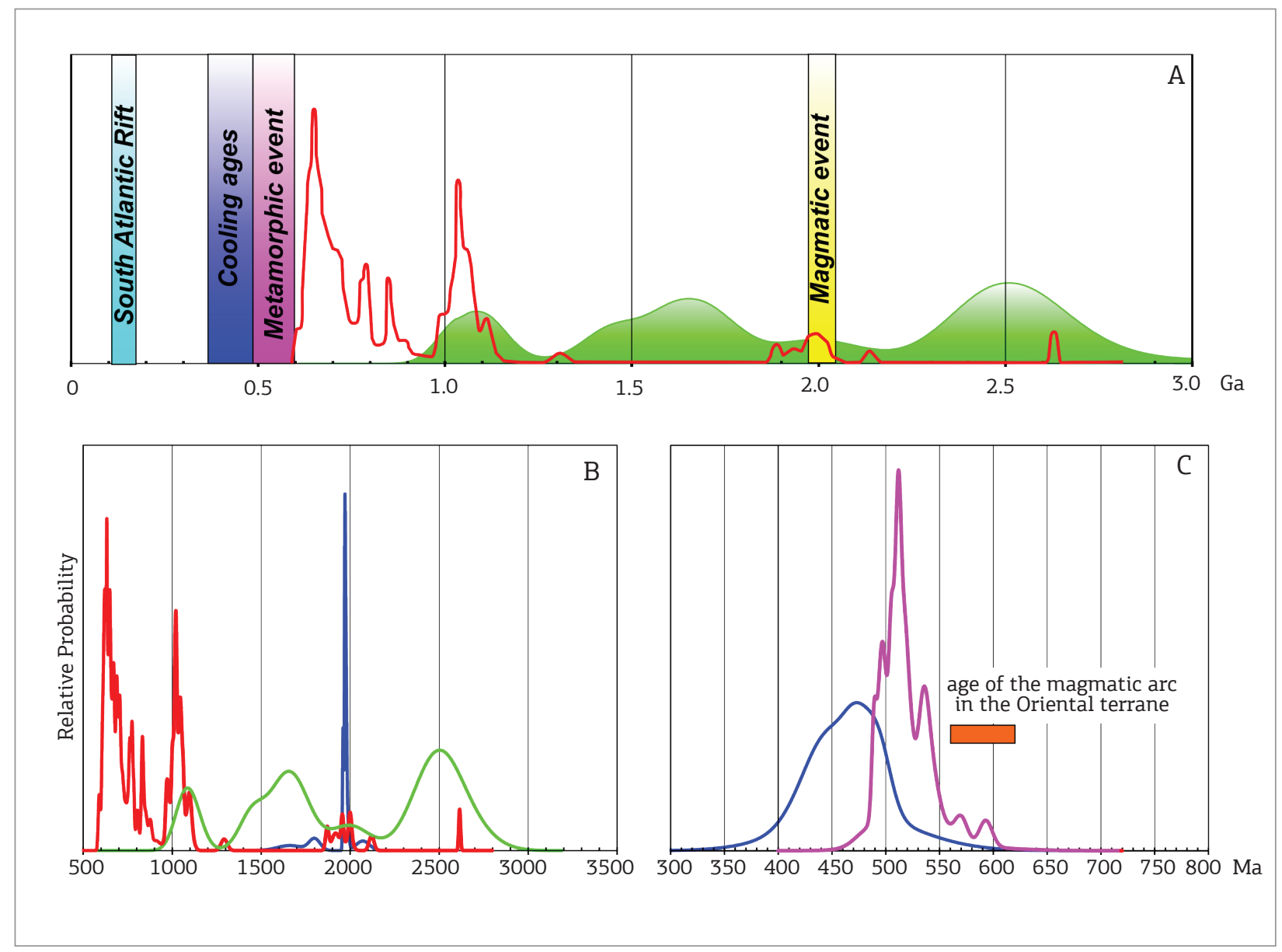

Figure 5. Cabo Frio Tectonic Domain geochronological barcode. (A) Schematic diagram of Cabo Frio Tectonic Domain ages. Green curve presents all $\mathrm{T}_{\mathrm{DM}} \mathrm{Nd}$ model ages for the Cabo Frio Tectonic Domain units. Red line present all detrital zircon populations obtained from the supracrustals of the CFTD. The magmatic event, metamorphic event, cooling ages and age of South Atlantic rifting are based on the data presented on Appendix I. (B) Relative probability against age diagram with: detrital zircon $\mathrm{U}-\mathrm{Pb}$ data (red line), zircon $\mathrm{U}-\mathrm{Pb}$ data for igneous rocks (blue line), and $\mathrm{T}_{\mathrm{DM}} \mathrm{Nd}$ model ages only for comparison (green line). (C) Detailed relative probability against age diagram with metamorphic zircon $\mathrm{U}-\mathrm{Pb}$ data (pink line) and Ar-Ar, $\mathrm{K}-\mathrm{Ar}$ cooling ages (blue line). 
According to Fernandes et al. (2015), more than $80 \%$ of the detrital zircon grains of the supracrustals are post1.2 Ga and pre-0.56 Ga, with the largest peak at $0.63 \mathrm{Ga}$ (Fig. 5A,B). These mostly magmatic sources have no correlative within the basement rocks of the CFTD or the Angola basement (Fig. 1B). However, these sources are present in the Oriental Terrane of the Ribeira Orogen (Figs. 1 and 2). This is key evidence that indicates that the supracrustals which are in tectonic contact with the Orosirian basement could be allochthonous to them and may have been only incorporated into the CFTD during the Buzios Orogeny. The minor Orosirian detrital zircon population could well represent sediments that were deposited on the margin of the Congo craton and were reworked during the convergence period that culminated with the continental collision in the Cambrian. Fernandes et al. (2015) suggest that the Palmital Succession sediments are associated with the São Fidelis Group, metasedimentary rocks that occur further west in the Oriental terrane (Fig. 3). They point out that these units could represent an accretionary prism deposit and a fore-arc deposit respectively. Sedimentary and volcanic layers from the Buzios Sucession would be related to a more oceanic realm, distal from the Ribeira arc continental margin (Fernandes et al. 2015). In both cases, the basement of the CFTD (together with the Angola Block) would either be far away from these basins or were not exposed at the time of the basin infilling.

Another important period of time that represents the barcode of the CFTD, besides the Orosirian, is the Cambrian (Figs. 5A and 5C). Metamorphic minerals and metamorphic rims were extensively dated with U-Pb method with a range between 540 and $490 \mathrm{Ma}$ and a peak at $515 \mathrm{Ma}$ (Fig. 5C) (Schmitt et al. 2004). This collisional orogeny lasted apparently ca. 60 m.y. and affected both the supracrustals and the basement rocks. The tectonic convergence was responsible for the high strain contacts between these units.

A range of $\mathrm{K}-\mathrm{Ar}$ and $\mathrm{Ar}-\mathrm{Ar}$ ages represents the cooling period of these high grade metamorphic rocks (Fig. 5C). Most cooling ages are ca. $470 \mathrm{Ma}$, but the whole group of ages defines a period from 510 to $400 \mathrm{Ma}$, entering the Devonian. This overlap of metamorphic and cooling ages is due to the diachronous tectonic evolution between the eastern region, which cooled earlier (with monazite concordant ages of $515 \mathrm{Ma}$ ) and the western region of the CFTD that cooled later (with monazite concordant ages of $495 \mathrm{Ma}$ ) (Schmitt et al. 2004).

Finally, the last striking tectonic event is the Gondwana break up at ca. $130 \mathrm{Ma}$ in this region and generation of the South Atlantic lithosphere. This age is represented by mafic dykes, basin formation, flood basalts and alkaline intrusions (Valente et al. 2007; Geraldes et al. 2013).

\section{The Paleoproterozoic Congo continental margin (the generation of the Cabo Frio Tectonic Domain)}

The Orosirian basement of the CFTD has no correlated counterpart in the Ribeira Orogen. Between the CFTD and the São Francisco Craton there are two terranes: the Oriental and Occidental Terranes (Heilbron et al. 2010) (Figs. 1 and 2). The basements of the Occidental Terrane and the Southern São Francisco Craton have no significant unit with Orosirian ages (Avila et al. 2010; Heilbron et al. 2010; Teixeira et al. 2015; Noce et al. 2007; Brito Neves 2011) (Figs. 1B, 6A).

By contrast, the Angola block (a part of the Congo Craton - Fig. 1A, 6A) contains several granites with Orosirian ages (Delor et al. 2006; Mc Court et al. 2013; Monié et al. 2012). The reworked margin of the Congo Craton in the Kaoko Belt (Namibia) also contains ca. 1.95 Ma granites (Seth et al. 1998). Hence, it can be inferred that the basement of the CFTD was part of the Angola Block as pointed out by several authors (Fonseca 1993; Fonseca et al. 2012; Zimbres et al. 1990; Schmitt et al. 2004).

The question is whether this Orosirian crust has any connection with the tectonic evolution of its counterpart along the southern São Francisco Craton margin (Fig. 6A). Avila et al. (2010) and Heilbron et al. (2010) agree that there was an accretion of continental and intraoceanic arcs that form the basement of the Occidental Terrane of the Ribeira Orogen (Juiz de Fora and Mantiqueira belts - Figs. 1B, 6A). This tectonic activity culminated with the collision of the intraoceanic Juiz de Fora arc with the São Francisco paleocontinent margin at ca. $2050 \mathrm{Ma}$ (Teixeira et al. 2015). In all models, to the east (today's position) of the Juiz de Fora domain there is an oceanic crust that separates it from the Orosirian Cabo Frio magmatic arc (Fig. 6A). Therefore, it seems reasonable to conclude that subduction towards the Angola block started after the accretion of the Juiz de Fora intraoceanic arc onto the southern margin of the São Francisco block (Fig. 6A).

One of the intriguing aspects of this piece of Orosirian lithosphere is the large lapse of time between the crystallization ages of the igneous complex $(1.99-1.94 \mathrm{Ga})$ and the metamorphic overprint in the Cambrian. Comparison with the classical Andean-type magmatic arc suggests that this complex was associated with a subduction zone. But there is no evidence that there was a collision after the subduction ceased (Fig. 6A). What happened to the oceanic crust between the Juiz de Fora and the CFTD arcs is, as yet, unexplained.

On the African side, following the Angola Block to the south, in Namibia, a ca. 1.8 Ga magmatic arc is present, about 100 m.y. younger than the Cabo Frio continental arc (Kröner et al. 2010) (Fig. 1, 6A). But these 1.8 Ga rocks show evidence of a high grade metamorphic overprint ca. 

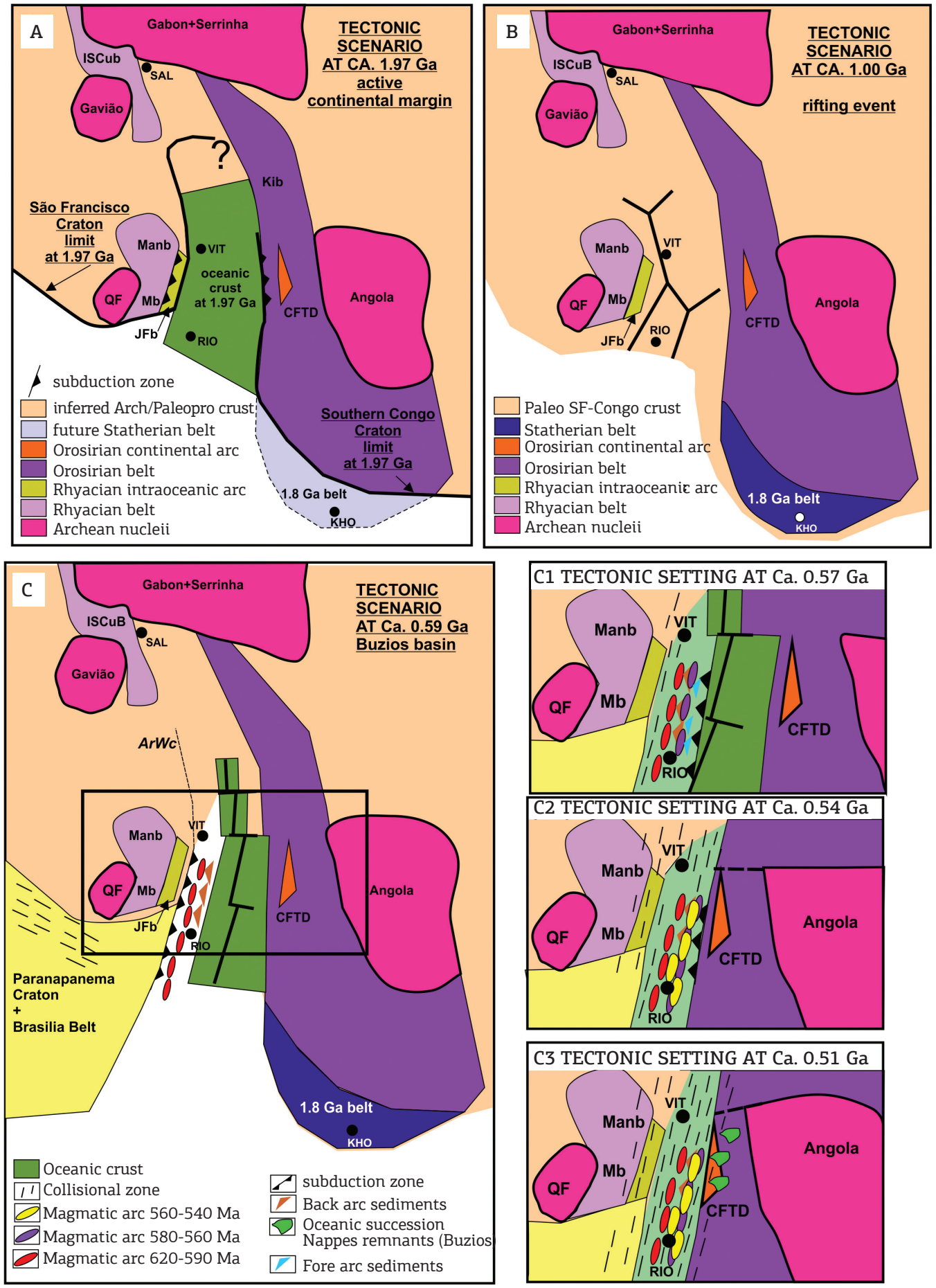

Figure 6. Proposed tectonic scenarios for the Cabo Frio Tectonic Domain from the Paleoproterozoic to the Cambrian. This schematic drawing is based on the geological map and reconstruction shown in figure 1B. For reference the cities of Rio de Janeiro (RIO), Vitória (VIT), and Salvador (SAL) in Brazil are indicated; and Khorixas (KHO) in Namibia (Africa). (A) Tectonic Scenario at ca. 1.97 Ga. Angola - Angola Archean block; Gavião - Gavião Archean block; Gabon+Serrinha - Gabon-Serrinha Archean block; QF - Quadrilatero Ferrifero block and adjacent Archean domains; ISCub - Itabuna Salvador Curaça belt; Mb - Mineiro belt; Manb- Mantiqueira belt; JFb - Juiz de Fora belt; CFTD - Cabo Frio Tectonic Domain; Kib - Kimezian belt. The Cabo Frio Tectonic Domain is in orange, positioned within the Orosirian crust of Angola Paleoproterozoic crust. (B) Tectonic Scenario at ca. $1.0 \mathrm{Ga}$. Note the beginning of rifting from south towards north in the São Francisco-Congo paleocontinent. (C) Tectonic Scenario at ca. $0.59 \mathrm{Ga}$. Note the development of an ocean floor referred to as the Buzios Basin. ArWc Araçuai-West Congo belt. (C1) detail from 6C at $0.57 \mathrm{Ga}$ (C2) detail from $6 \mathrm{C}$ at $0.54 \mathrm{Ga}$. (C3) detail from $6 \mathrm{C}$ at $0.51 \mathrm{Ga}$. 
1.7 Ga (Seth et al. 2003; Kröner et al. 2010). This event is attributed to a collision with an unknown block that did not affect the northern part in Angola.

\section{The Neoproterozoic continental margin (the thinning of the Cabo Frio Tectonic Domain)}

The scarcity and even absence of Mesoproterozoic rocks in the CFTD and the Ribeira Orogen indicates that the major magmatic event that developed in southern Angola and northern Namibia did not affect this portion (De Waele et al. 2008 - Fig. 1B). The only rocks recognized from the end of this era are some dykes and granites that crystallized in the Araçuai-West Congo and Ribeira belts indicating a Tonian rifting event (Fig. 6B, Silva et al. 2008, Tack et al. 2001).

Detrital zircon from this Tonian event is preserved in the supracrustals of the Buzios-Palmital Group (Schmitt et al. 2004, Fernandes et al. 2015), but no influence of this extensional event is recognized in the Paleoproterozoic basement of the CFTD. Therefore, these sources are probably related to one of the rifting events documented for the São Francisco-Congo craton at ca. 1.0 Ga (Fig. 6B) (Tupinamba et al. 2007b; Pedrosa Soares \& Alkmim 2011). Evidence for this restricted sea or ocean is described to the north in the confined Araçuai Orogen (Pedrosa Soares et al. 1998) and also to the west in the Ribeira Orogen, between the Occidental and the Oriental terranes (Heilbron \& Machado 2003) (Fig. 2).

The principal evidence for extension of the basement in the CFTD is the abundance of mafic N-MORB tholeiitic dykes that cut this unit (Fig. 4C) and which are contemporaneous with the Buzios succession (Schmitt et al. 2008a). There are only few detrital zircon grains from this extensional event interval dated in the supracrustals of the Palmital and São Fidelis units (Fernandes et al. 2015). The reason might be that the main magmatic source is mostly tholeiitic mafic juvenile rocks, or because the sedimentary basins were far from the source.

Therefore, we propose here that the Buzios basin developed in an oceanic environment as an extension of the passive continental margin of the Angola block (Congo Craton) (Fig. 6C). The contrasting crustal nature between the juvenile sediments and volcanic layers from the Buzios succession and the granitic Paleoproterozoic basement of the CFTD does not eliminate the hypothesis that this contact is primary. These oceanic sediments and volcanics could have been deposited directly on a hyper-extended continental crust of the Congo craton margin. The fact that there are abundant mafic tholeiitic dykes cross-cutting the Paleoproterozoic basement could also support that this basement was a transitional crust in a distal continental margin that went through a thinning process due to rifting. Therefore, this piece of lithosphere could represent a Late Neoproterozoic ocean-continent transition zone, favorable for attaining high P-T conditions during a subsequent collisional event (Beltrando et al. 2010).

The age of the deposition of the Buzios succesion coincides with the age range of the Oriental Terrane magmatic arc (Rio Negro arc in Fig. 2). Because of this, and considering the interpretation that this arc was a product of the subduction of the eastern margin of the São Francisco paleocontinent to $\mathrm{SE}$, the Buzios basin would be interpreted as a back-arc basin according to its tectonic position (Fig. 6C; Basei et al. 2008; Heilbron \& Machado 2003; Tupinamba et al. 2000, 2012; Heilbron et al. 2008; Schmitt et al. 2008; Fernandes et al. 2015). This subducting oceanic plate had apparently no links with the Buzios basin and was formed at ca. $840 \mathrm{Ma}$ (Heilbron \& Machado 2003). It probably extended to the north, linking with the Araçuai ocean floor (Pedrosa Soares et al. 1998) (Fig. 6C).

The thinning of Congo continental crust took place at ca. $610 \mathrm{Ma}$ (age of the mafic volcanics of Buzios succession - Schmitt et al. 2008a) and could be a result of the steepening of the subduction zone of the Rio Negro oceanic crust to the west prior to collision. The extension on the back-arc setting would result in the formation of the Buzios succession with oceanic floor formation. This subduction process stopped at ca. $585 \mathrm{Ma}$, when the arc collided with the Sao Francisco craton margin, according to Heilbron \& Machado (2003), based on metamorphic ages obtained in the Occidental Terrane.

During the interval $580-570 \mathrm{Ma}$, while there was an arc-continent collision in the Araçuai and Ribeira orogens to the west, the Buzios ocean floor spreading was interrupted (Fig. 6C, $\mathrm{C} 1)$. The occurrence of calc alkaline magmatic plutons of $570-540 \mathrm{Ma}$ in the eastern border of the Oriental terrane is interpreted here as a consequence of the consumption of the Buzios ocean plate by subduction towards the west due to convergent tectonics (Figs. 3 and 6C1,2).

The Palmital succession is considered to be deposited in a younger basin in an active pre-collisional margin, associated with the erosion of the magmatic arc of the Ribeira Orogen and also of the Coastal Terrane of the Kaoko Belt (Fig. 1). Fernandes et al. (2015) argue that Palmital turbiditic-derived sediments can be correlated with the São Fidelis Group, a major unit of the Oriental Terrane (Fig. 3). In their interpretation, this unit would correspond to an accretionary prism and the São Fidelis Group to a fore-arc basin. Both units have the same provenance and a similar signature on the $\varepsilon \mathrm{Hf}(\mathrm{t})$ diagram evolution, and they could be related to the same tectonic environment. They are both located to the east of the arc-domain within the Oriental 
terrane, which is their main sedimentary source according to Fernandes et al. (2015) (Fig. 3). This region could have been a back-arc environment at ca. $620 \mathrm{Ma}$, evolving to a fore-arc setting at ca. $590 \mathrm{Ma}$, when subduction shifted to the back-arc domain (Figs. 6C, C1). During this change, Archean/Paleoproterozoic rocks from the Angola Block/ Cabo Frio Tectonic Domain and its sedimentary cover transformed into an active margin and their reworking provided the Paleoproterozoic and Archean detrital zircon population for the Neoproterozoic supracrustals (Fig. 6C2).

\section{The significance of the Buzios Orogeny (the thickening of the Cabo Frio Tectonic Domain)}

The closure of the back-arc basin was only possible with the subduction of the Buzios oceanic crust to the west, beneath the Oriental terrane (Schmitt et al. 2008b) (Fig. 6C1 and 7). The collision between the Rio Negro magmatic arc and the margin of the São Francisco paleocontinent at ca. 585 Ma further west (Heilbron \& Machado 2003) could have triggered the subduction of the Buzios oceanic plate, generating a break off on the transitional continental to oceanic crust boundary in the back-arc region (Fig. 6C1). The consequence of this late Neoproterozoic subduction was the continental collision of the Congo lithospheric plate with the Oriental Terrane in the Cambrian (Fig. 6C3 and 7).

Three main lines of evidence support the subduction of the Buzios oceanic plate: (a) calc-alkaline plutons of 570 $540 \mathrm{Ma}$ in the Oriental Terrane, (b) the structural framework of the CFTD and (c) high temperature-medium to high pressure metamorphism on the Buzios succession.

The first line of evidence consists of the extensive magmatic province with ages between 570 and $540 \mathrm{Ma}$ that occurs in the eastern part of the Oriental Terrane close to the tectonic contact with the western part of the CFTD (Figs. 3 and 6C1, -2, -3, and 7) (Silva et al. 2003; Mendes et al. 2006; Schmitt et al. 2012a). These calc alkaline plutons were previously interpreted as syn-to post-collisional plutons, with respect to the collision between the Rio Negro Arc (630 $590 \mathrm{Ma}$ ) with the margin of the São Francisco Craton to the northwest, in the period 590 - $560 \mathrm{Ma}$ (Fig. 2) (Heilbron \& Machado 2003; Heilbron et al. 2008). These authors propose that the closure of the Buzios back-arc basin would be due to subduction towards the east. No Neoproterozoic-Cambrian magmatic arc rocks have been reported on the Angolan side of the orogen to support this hypothesis (Fig. 1). We propose alternatively that the ca. 570 - 540 granitoids were related to a subduction zone of the back-arc oceanic crust towards the west, below the Oriental Terrane (Fig. 6C1, 2 and 7). These calc alkaline intrusions show evidence of localized migmatisation and ductile deformation within shear zones.
Their igneous zircon, with 570 - $540 \mathrm{Ma}$ ages, commonly has metamorphic rims dated at ca. $525 \mathrm{Ma}$ (Schmitt et al. 2012a). Therefore, it is most likely that these magmatic rocks are products of the subduction of the Buzios oceanic plate towards the west, and that they were affected by metamorphism related to the subsequently Cambrian collision.

Geological mapping showing the CFTD continental crust to be underneath the Oriental Terrane provides the second line of evidence for this new interpretation (see geological cross section of Fig. 3). This contact is folded by a megascale reclined structure with axis plunging to SW. This folding phase which post-dates the metamorphic peak (Fig. 4E) might correspond to the D3-folding phase, identified more clearly in the eastern part of the CFTD. This fold is also responsible for the inverted contact in the northern region of the CFTD that was interpreted before as a thrust contact of the CFTD onto the Oriental Terrane (Schmitt et al. 2004). This contact is better exposed in the western region of the CFTD where the Paleoproterozoic basement is underneath the Palmital Succession (Fig. 3). Kinematic indicators along this contact between the basement and supracrustals indicate top to E-ENE movement in the Ponta Negra region (Figs. 3 and $4 \mathrm{G}$ ). This would suggest that the supracrustals that today are on top of the basement within the CFTD were transported tectonically from W-SW, e.g. from the Oriental Terrane (Figs. 3, 6C3 and 7).

Stanton et al. (2010) identified a major magnetic anomaly that coincides with the contact between the CFTD and the Oriental Terrane in this region, which they interpreted as related to a suture zone.

The third and most striking line of evidence is the metamorphic grade of the Buzios supracrustal rocks. These medium to high $\mathrm{P}$ and high $\mathrm{T}$ granulites suffered metamorphism at depths of at least $40 \mathrm{~km}$, coherent with a subduction zone environment. It is noteworthy that this unit presents the highest pressure metamorphic assemblage within the entire Ribeira Orogen.

But there is some conflict with the occurrence of these high-P granulites (Buzios succession) in a back-arc environment. We adopted the back-arc hypothesis mostly based on the presumed subduction of the eastern São Francisco continental margin to SE at ca. 620 - $590 \mathrm{Ma}$ (Heilbron \& Machado 2003). Other alternatives are yet to be proposed. Back-arc regions would produce oceanic plates too hot and young to undergo fast subduction to deep levels and generate high-P rocks. We do not eliminate the possibility that the subduction zone pre-Ribeira collision would have been always towards NW, and the Buzios oceanic plate would be the last portion to subduct and collide. Therefore, the Ribeira Orogen main suture would be the CFTD suture with the Oriental Terrane. 


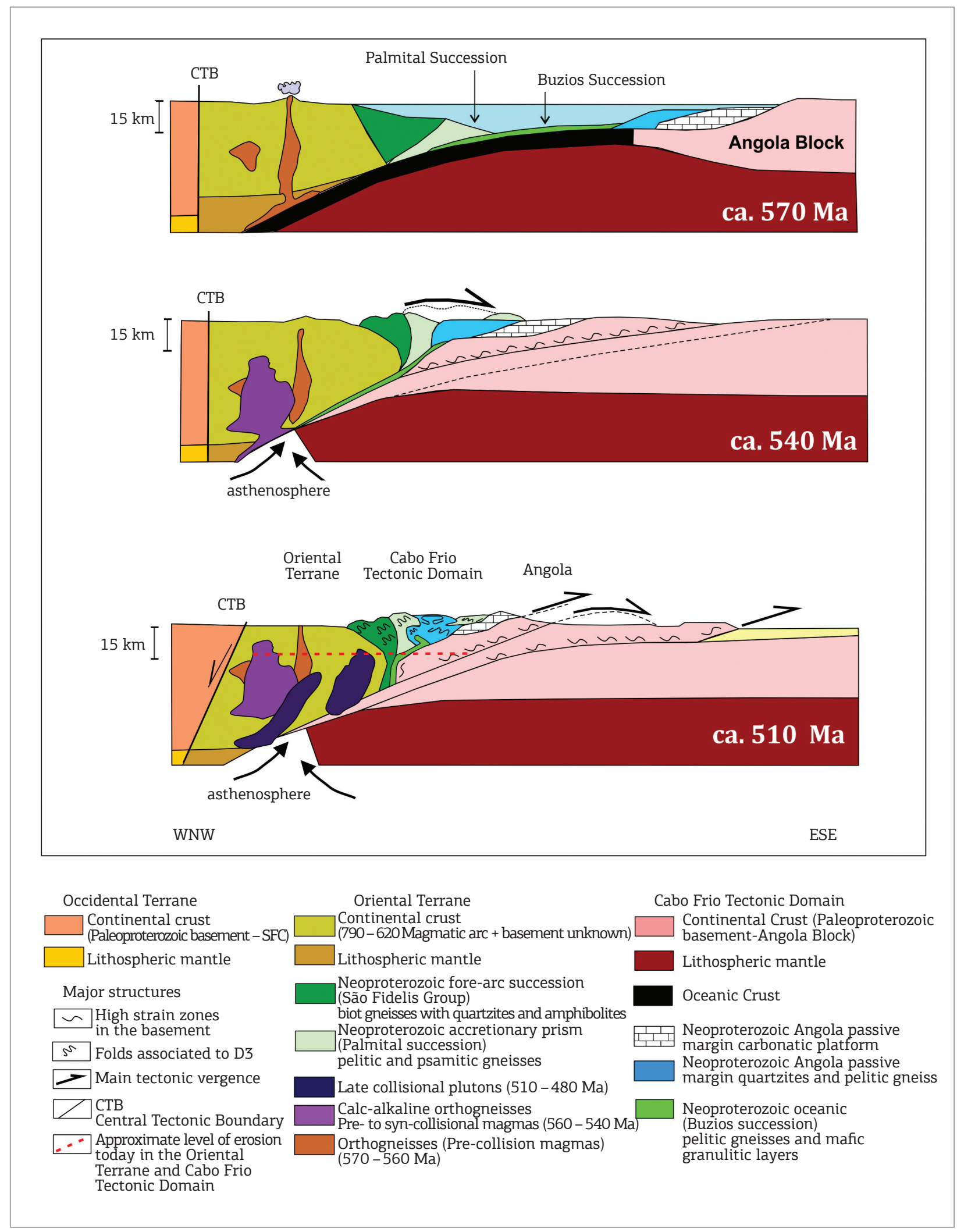

Figure 7. Three stage schematic model for the subduction of the Buzios Oceanic plate and subsequent continental collision between the Angola block and the Oriental Terrane (Ribeira Orogen) during the Cambrian. Each stage corresponds to the tectonic scenarios from Figure 6: 6C1, 6C2 and 6C3, at $570 \mathrm{Ma}, 540 \mathrm{Ma}$ and $510 \mathrm{Ma}$ respectively. The WNW-ESE orientation is approximate for the actual position of the terranes. The actual attitude of the CTB structure is only represented in the tectonic scenario of $510 \mathrm{Ma}$. We left the CTB as a subvertical structure in the ca. $570 \mathrm{Ma}$ and ca. $540 \mathrm{Ma}$ scenarios, only for reference since we do not know how it was originally oriented. 
Another intriguing question is whether the basement has undergone the same P-T conditions as the supracrustals. Both units present concordant tectonic foliation and stretching lineation, especially along the contacts, though the basement shows an E-W lineation in the less strained domains that is not recognized in the supracrustals. The mafic dykes (now orthoamphibolites) that cross-cut the basement granitoids present cpx+garnet+plg+qzt compatible with medium- to high-pressure granulite facies. Along these tectonic contacts and in the shear zones, the basement is strongly deformed and migmatized, and presents Cambrian metamorphic zircon of ca. $505 \mathrm{Ma}$ (Schmitt et al. 2004, 2008). This is partially compatible with the biotite Ar-Ar age of ca. $507 \mathrm{Ma}$ obtained in the basement, and with amphibole Ar-Ar age of $536 \mathrm{Ma}$ (Fonseca 1993). Rb-Sr whole rock age dating in the basement did not show resetting during the Cambrian tectonic event and $\mathrm{K}$-Ar ages reveal continued cooling between $494-434 \mathrm{Ma}$ for the basement (Delhal et al. 1969; Zimbres et al. 1990; Fonseca 1993). The sedimentary-volcanic units were probably subducted to deeper crustal levels and were exhumed and extruded during the collision as nappes (Figs. 6C3 and 7) that were folded together with the basement during D3 (Figs. 3 and 6C3 and 7). Because of severe weathering and erosion, these nappes are mostly unidentified and remain as isolated klippen.

The continental collision that resulted in the Buzios Orogeny started when the subduction ceased and part of the Congo continental margin underwent subduction with the slab pull of the oceanic crust (Fig. 7). This started at ca. $540 \mathrm{Ma}$ and its related tectonic processes continued until ca. $500 \mathrm{Ma}$. The age of the syntectonic $\mathrm{D}_{1-2}$ leucosome veins of the supracrustals $(530 \mathrm{Ma})$ associated with the metamorphic peak in the CFTD $(530-500 \mathrm{Ma})$ and the Oriental Terrane $(550-530 \mathrm{Ma})$ are interpreted as evidence for this collision. The ductile structures developed during progressive syn- to late-metamorphic deformational phases from 540 until ca. $500 \mathrm{Ma}$. This is coherent with the distinct cooling paths of the supracrustals. The Buzios succession rocks, which occur along the coast to the east of the CFTD, cooled faster and earlier than the Palmital succession, which occurs to the west in the suture zone that corresponds to the contact between the CFTD and the Oriental Terrane (Fig. 3). The Buzios succession could be a remnant of nappes that extruded during the beginning of the collision, ascending faster through the crustal ductile channels, preserving the high P-T mineral assemblage (Fig. 6C3). Monié et al. (2012) presented a similar sequence of high grade metasediments thrust towards the east over a high grade Paleoproterozoic basement of the Angola coast, correlating this tectonic association with the CFTD units (Figs. 6C3 and 7). These authors also obtained a Cambrian age for the metamorphic peak. Their geological cross section shows that the tectonic style changes from thick- to thin-skinned further east from the coast whereas the metamorphic grade of the sedimentary units diminishes. In addition, the sedimentary rocks that cover the Angola craton present more proximal facies such as quartzites (Fig. 7). Therefore, the CFTD would represent the internal parts, and the Neoproterozoic units of the Angola block the external parts of this Cambrian orogen (Fig. 7).

Another issue is the continental crust hidden today on the Atlantic platforms. In this region and its counterpart in Angola, at least $250 \mathrm{~km}$ of continental crust is missing from today's geological record (Chang et al. 1992). There is the possibility that the Cabo Frio Paleoproterozoic crust could have been an H-block in the Neoproterozoic extended margin of the Angola Block. This could be sustained if we considered that the width of the high grade metamorphic belt would be almost $300 \mathrm{Km}$ adding the outcrops in CFTD, the hidden continental crust plus the Angolan coastal outcrops. (Fig. 1). The thickness and geometry of this Neoproterozoic continental margin are still a matter of debate, and it seems more likely that the small part of the Cabo Frio Tectonic Domain that is exposed today represents the suture zone with the Oriental Terrane. The contact between the Buzios succession, interpreted as an oceanic sequence, with the Paleoproterozoic continental crust would then be the suture of the continental collision. This suture crops out in several places with different orientations due to the deformational phases that folded and refolded this contact during collision (Fig. 7).

The Buzios orogeny represents the last collisional episode of the Ribeira belt and marks the end of the Gondwana amalgamation in this region (Fig. 8). The closest coeval collisional orogeny is registered in the Damara Orogen (see location on Fig. 8). The occurrence of a similar Cambrian belt along the coast of Angola (Monié et al. 2012) leads to the conclusion that it is most likely that the actual continental margin between Rio de Janeiro and Angola is represented by the CFTD units. Therefore, this Cambrian collisional orogeny represents a larger belt that is mostly submerged today.

\section{The third continental margin}

The Gondwana collage in this sector remained welded until the initiation of the South Atlantic rifting event at ca. 140 Ma (Fig. 8; Nurnberg and Müller 1991), when the São Francisco and Congo blocks were finally separated (Figs. 1 and 8). For the third time, the Cabo Frio Tectonic Domain became part of a continental margin, but now on the Brazilian side. One of the intriguing questions is why the break up in southeast Brazil did not occur along one of the sutures of the Ribeira belt. It could have followed the western suture of the Oriental Terrane with the Occidental 


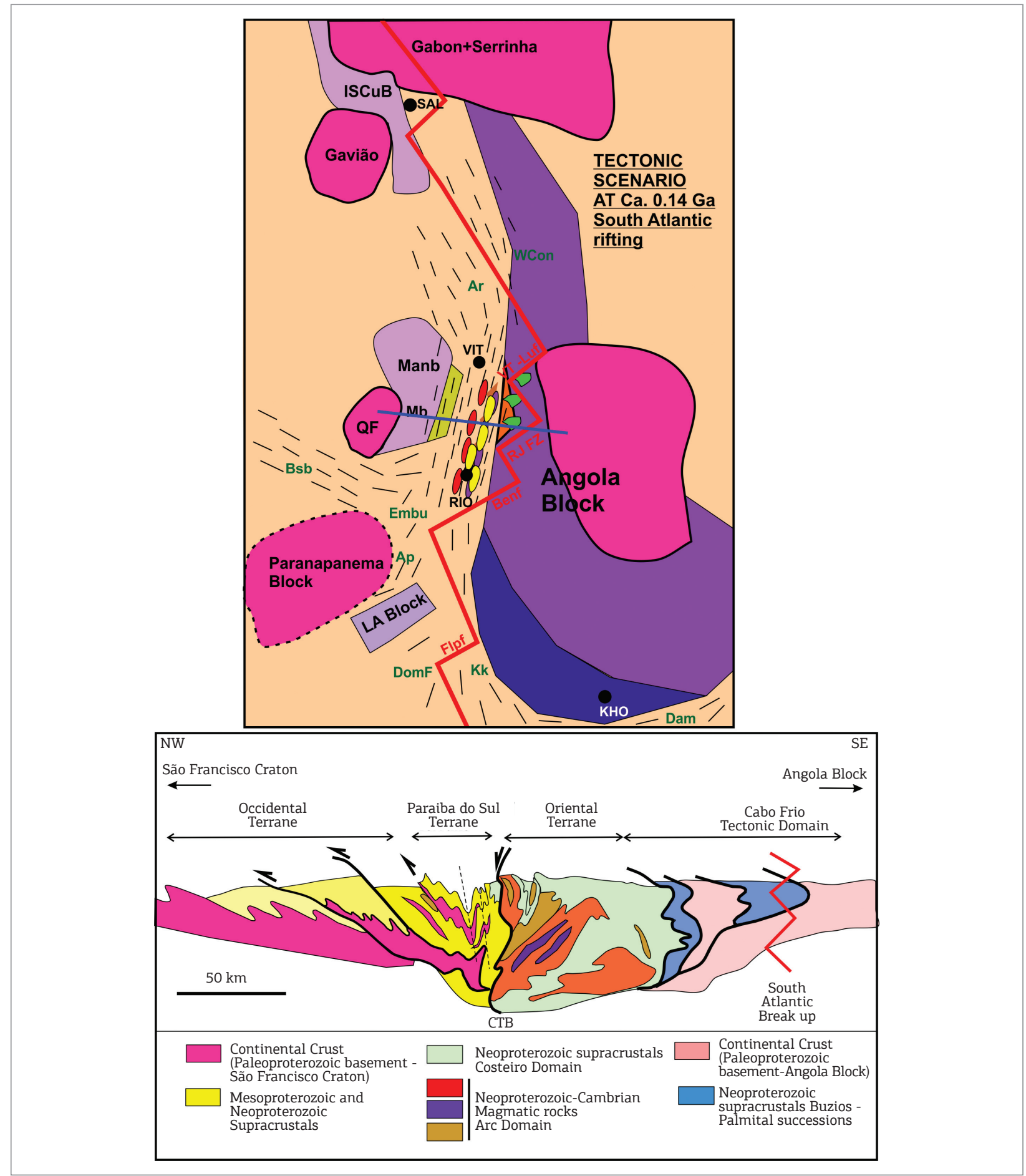

Figure 8. Tectonic cartoon of the South Atlantic rifting at ca. $140 \mathrm{Ma}$ with the main fracture zones and future spreading centers in red (complementary legend on Fig. 6). This schematic drawing is based on the geological map and reconstruction shown in Figure 1B. For reference the cities of Rio de Janeiro (RIO), Vitória (VIT) and Salvador (SAL), in Brazil are indicated; and Khorixas (KHO) in Namibia (Africa). Fracture zones: Flpf - Florianópolis fracture zone; Benf - Benguela fracture zone; RJFZ - Rio de Janeiro fracture zone; VT-Luf - Vitoria-Trindade-Luanda fracture zone. Mobile Neoproterozoic-EoPaleozoic belts are shown in the regions with traces, named: Bsb - Brasilia belt; Ar - Araçuai Belt; WC - West Congo belt; Rib - Ribeira Belt; Embu - Embu terrane; Ap - Apiaí terrane; DomF - Dom Feliciano Belt; Kk - Kaoko belt; Dam - Damara Belt. For additional information, see also the legend of Figure 6. Below there is a model for a proposed geological cross section through the Ribeira Orogen from the São Francisco Craton to the NW through the Angola Block to the SE, modified from Heilbron et al. (2013). The section is marked as a blue line on the schematic map. See also the estimated line of Mesozoic South Atlantic break up in this Neoproterozoic lithospheric architecture. 
terrane (the Central Tectonic Bounday (CTB) - Almeida et al. 2013) or the suture between the Cabo Frio Tectonic Domain and the Oriental Domain (see Figs. 2, 3, 7 and 8). Essentially, the break up of the central segment of the South Atlantic occurred within the ancient continental margin of the Angola block (the CFTD).

Along the modern continental margin of Southeast Brazil, onshore subparallel NE-SW rifting structures characterize the main structural direction of this rifted system (Asmus and Gazelli 1981; Chang et al. 1992). The offshore basins cumulate thick sedimentary sequences and are very prolific in oil and gas, in response to intense and favorable tectonic and magmatic activity since the Cretaceous. Interestingly, the general structural configuration of the margin changes between the Santos and Campos basins, displaying E-W trends and basin's offshore depocenters to the south of the CFTD (Asmus \& Gazelli 1981; Chang et al. 1992; Stanton et al. 2014), with several NW-SE transfer structures and basement blocks, which can be correlated with transfer zones and faults onshore (Stanton et al. 2014).

Potential field data revealed an en echelon structural pattern characterizing the proximal part of this segment of the margin, interpreted as the result of oblique rifting during the Mesozoic that was associated with deep seated magmatic bodies (Stanton et al. 2014) and Moho uplift (Meisling et al. 2001). The offshore region adjacent to the CFTD comprises the Campos and Santos Magnetic Highs, the most prominent magnetic anomalies of the Southeast Brazilian margin (Stanton et al. 2010; Stanton \& Schmitt 2015), which affect the continental basement onshore and offshore. The Santos Magnetic High (SMH) shows a clear prolongation from the CFTD offshore into the Santos Basin. Onshore the geometrical and field relationships between the magnetic anomalies and the brittle structures suggest that they are associated with the Serra do Mar Dyke Swarm (Stanton \& Schmitt 2015), while offshore the forward modeling indicates the presence of mafic and ultramafic magmatic superficial and deep intrusions, probably related to the rift phase (Stanton et al. 2010). In addition, there is an offshore prolongation of the Cabo Frio Tectonic Limit towards the Campos Basin, where it possibly delimits the northern boundary of the São João da Barra Graben (Stanton \& Schmitt 2015), indicating basement control on the margin architecture (Fig. 2).

The important role of preexisting structures at the formation of rifted margins is generally accepted (Tommasi \& Vauchez 2001; Buiter \& Torsvik 2013). Nevertheless, the presence of NE-SW extensional, rift-related structures throughout the CFTD, which constitutes a distinct terrane with differing structural framework from the rest of the Ribeira Belt, shows local exceptions to such a straightforward relationship. If rifts follow ancient orogenic belts, as generally presumed, why did this not occur at the central Ribeira Belt where it shifted to the east, breaking along the CFTD? In the light of the present knowledge of the offshore crustal structure, the presence of magmatism at the first stages of rifting may have influenced the process. The melt produced during extension could have migrated laterally, guided by existing differences in crustal thickness, inherited from the Gondwana amalgamation events. According to the crustal thickness map of Assumção et al. (2002), there is a crustal thinning southeastward across the Ribeira Belt to the CFTD. Whether this thinning was inherited from previous tectonic events or whether it is the result of Mesozoic crustal extension is not known. However, it may have potentially facilitated the melting concentration and/or migration towards the region of thinner crust under the CFTD. The existence of regions of crustal weakness acting as conduits for the magmatism has been proposed by Valente et al. (2007) to explain the differing geochemical signatures observed for the low Ti mafic dykes along the CFTD. This is coherent with the presence of magmatic bodies sources for the observed magnetic and gravity highs onshore and offshore the CFTD (Stanton et al. 2010). As proposed by several authors, magma facilitates rifting (Cortiet al. 2003; Ebinger 2005); the stress required for extensional separation is smaller if magma is involved while localized deformation favours major accumulation of magma at transfer zones (Corti et al. 2002). Therefore, the accommodation of the deformation by a combination of dyke intrusion and faulting could result in a positive feedback between deformation and magmatism, and the CFTD would be a "preferable" site for rifting.

Secondly, lateral variations in crustal rheology at this portion of the margin are expected since the CFTD differs tectonically and compositionally from the western Ribeira Orogen. As rifted margin evolution depends on various parameters, like temperature, rheology, mode of extension, etc., the natural intrinsic differences result in complex architectures. The offshore Santos and Campos basins, though juxtaposed, are structurally very different and affected by intense segmentation: they are separated by the regional Rio de Janeiro Transfer Zone (RJTZ), associated with the structural inflexion from NE-SW to E-W trends offshore from the CFTD. To the south of the CFTD, crustal thickness maps and seismic results show a region of abrupt crustal necking and thinning (Scotchman et al. 2010; Stanton et al. 2014), indicating a deep crustal structure separating different marginal domains. This crustal structure could be associated with the RJTZ and may represent the southern limit of the CFTD offshore (Stanton et al. in preparation). In this context, the differences in structure and rheology associated with the CFTD could have influenced the pattern of segmentation 
and magmatism of the southeast Brazilian margin during its early stages. As suggested by Buiter \& Torsvik (2014), rifting seems to be initiated by tectonic forces and plume material flows to the thinned rifted lithosphere to help trigger final continental break-up.

\section{CONCLUSION - DEFINITION AND SIGNIFICANCE OF THE CABO FRIO TECTONIC DOMAIN}

The Cabo Frio Tectonic Domain is the onshore exposure along the SE Brazilian coast of a larger terrane with Paleoproterozoic continental crust that was later subjected to a Cambrian collisional orogeny and a Cretaceous rifting event, producing a unique geochronological barcode. There is strong evidence that it should be correlated with the western domain of the Angola block, in Africa.

Through its evolution, the CFTD became part of continental margins on three occasions. During the Orosirian (ca. $1.97 \mathrm{Ga}$ ), it was generated as a continental magmatic arc in an active margin setting at the western limit of the Archean Kasai domain, in the Angola Block (southwestern Congo Craton). There is no evidence that the end of this tectonic activity terminated with a continental collision in this area, although the São Francisco-Congo blocks were already joined by this process to the north. The SF-Congo Paleocontinent went through several extensional events afterwards, but the only rifting event that is registered in the CFTD may correspond with the Late Neoproterozoic formation of the Buzios oceanic basin. The high frequency of tholeiitic mafic dykes cross-cutting the Paleoproterozic basement could indicate that this continental crust was considerably thinned and was very close to the COB line (Continental-Oceanic boundary). The tectonic inversion to a convergent setting culminated with a major continental collision involving the Angola block (with the Cabo Frio Tectonic Domain) and the Neoproterozoic Oriental Terrane (part of the Ribeira Orogen) during the Cambrian (Buzios Orogeny 540 $490 \mathrm{Ma}$ ). The CFTD contains mafic and ultramafic rocks which were remnants of the Late Neoproterozoic oceanic floor and metamorphosed at high P-T conditions (Buzios succession). This corroborates with the hypothesis that ocean-continent transitions are in positions favorable to reach (ultra) high-pressure conditions, following negatively buoyant oceanic lithosphere into subduction, and then being accreted to the orogen in response to the arrival of more buoyant continental lithosphere that resisted subduction (Beltrando et al. 2010).
It is likely that the small part of the Cabo Frio Tectonic Domain that is exposed today represents the suture zone with the tectonic plate of the Oriental Terrane. The contact between the Buzios succession, interpreted as an oceanic sequence, with the Paleoproterozoic crust would be the suture of the continental collision. The CFTD represents the internal part of the orogen, and the transition to the external domain within the Congo Craton is only preserved in the onshore segment of its counterpart in Angola. The Buzios orogeny represents the last collisional episode of the Ribeira Orogen and marks the end of the Gondwana amalgamation in this region. The occurrence of a similar Cambrian belt along the coast of Angola (Monié et al. 2012) leads to the conclusion that it is most likely that the actual continental margin between Rio de Janeiro and Angola is represented by the CFTD units. Therefore, this Cambrian collisional orogeny could well be a major belt that is mostly submerged today.

During the Cretaceous, the break up of the central segment of the South Atlantic occurred within the ancient continental margin of the Angola block (the CFTD). The reactivation of continental margins is due to inherited heterogeneities that control the rifting processes (Manatschal et al. 2007; Beltrando et al. 2010, 2014). In this context, the differences in structure and rheology associated with the CFTD could have influenced the pattern of segmentation and magmatism of the southeast Brazilian margin during its early stages. As suggested by Buiter \&Torsvik (2014), rifting seems to be initiated by tectonic forces and plume material flows to the thinned rifted lithosphere to help trigger final continental break-up.

In conclusion, the Cabo Frio Tectonic Domain is a good example of tectonic reactivation of ancient sutures between lithospheric domains, but the role of inherited structures in the face of thermal input and tectonic forces must be further investigated.

\section{ACKNOWLEDGEMENTS}

R.S.S. thanks CNPq and FAPERJ for the research grants n. 302996/2009-5 and n. E-26/102.260/2009, respectively; and CENPES-PETROBRAS for support with the project "Revisão do Mapa Geológico do Gondwana" (CENPESUFRJ/13850). This paper is a contribution to the IGCP628 "The Gondwana Map Project - the geological map and the tectonic evolution of Gondwana". R.A.J.T. acknowledges $\mathrm{CNPq}$ for a research grant. We also would like to thank Dr. Cesar Casquet and an anonymus reviewer for suggestions and comments that improved our paper. 


\section{REFERENCES}

Almeida J., Dios F., Mohriak W.U., Valeriano C.D.M., Heilbron M., Eirado L.G., Tomazzoli E. 2013. Pre-rift tectonic scenario of the EoCretaceous Gondwana break-up along SE Brazil-SW Africa: insights from tholeiitic mafic dyke swarms. In: Mohriak W.U., Danforth A., Post P.J., Brown D.E., Tari G.C., Nemcok M. \& Sinha S.T. (eds). Conjugate Divergent Margins. Geological Society, London, Special Publications, 369:11-40.

Almeida J., Heilbron M., Pascutti A.H.F.G., Silva T.M., Tupinambá M., Dios F., Silva L.G.E., Valeriano C., Duarte B., Schmitt R.S., Valladares C.S., Nogueira J.R., Ragatky C.D., Valente S., Souza D.M., Azevedo R., Costa M., Viana S.M., Geraldes M.C., Souza M.P.G., Martins M.A.M., Menezes P.T.L., Mane M.A., Martins P., Carvalho F.H., Mello R.P., Palermo N., Guimarães P.V., Silva F.L., 2009. Mapa Geológico da Folha Macaé SF.24-Y-A-I. Belo Horizonte: CPRM, CD-ROM.

Asmus H.E. \& Gazelli W. 1981. Descrição sumária das estruturas da margem continental brasileira das áreas oceânicas e continentais adjacentes: hipóteses sobre o tectonismo causador e implicações para os prognósticos do potencial de recursos minerais. Serie Projeto REMAC, Rio de Janeiro, 9:187-269

Assumpção M., James D., Snoke A. 2002. Crustal Thickness in SE Brazilian Shield by receiver function analysis: Implications for isostatic compensation. Journal of Geophysical Research, 107(B1):1-14.

Ávila C.A., Teixeira W., Cordani U.G., Moura C.A.V., Pereira R.M. 2010. Rhyacian (2.23-2.20 Ga) juvenile accretion in the Southern São Francisco craton, Brazil: Geochemical and isotopic evidence from the Serrinha magmatic suíte, Mineiro belt. Journal of South American Earth Sciences, 29:464-482.

Basei M.A.S., Frimmel H.E., Nutman A.P., Precciozi F. 2008. West Gondwana amalgamation based on detrital zircon ages from Neoproterozoic Ribeira and Dom Feliciano belts of South America and a comparison with coeval sequences from southwestern Africa. In: Pankhurst R.J., Trouw R.A.J., Brito Neves B.B., De Wit M.J. (eds.) West Gondwana: Pre-Cenozoic Correlations across the South Atlantic Region. Geological Society, London, Special Publications, 294:239-256.

Begg G.C., Griffin W.L., Natapov L.M., O’Reilly S.Y., Grand S.P., O’Neill C.J., Hronsky J.M.A. 2009. The lithospheric architecture of Africa: Seismic tomography, mantle petrology and tectonic evolution. Geosphere, 5:23-50.

Beltrando M., Manatschal G., Mohn G., Dal Piaz G.V., Brovarone A.V., Masini E. 2014. Recognizing remnants of magma-poor rifted margins in high-pressure orogenic belts: The Alpine case study. Earth-Science Reviews, 131:88-115.

Beltrando M., Rubatto D., Manatschal G. 2010. From passive margins to orogens: The link between ocean-continent transition zones and (ultra) high-pressure metamorphism. Geology, 38(6):559-562.

Bongiolo E., Renac C., D’Almeida de Toledo P., Schmitt R.S., Faulstich F.R.L., Mexias A.S., Silva F.P.C. 2015. Origin of pegmatites and fluids at Ponta Negra (RJ, Brazil) during late- to post-collisional stages of the Gondwana Assembly. Lithos, 240:259-275.

Brito Neves B.B. 2011. The Paleoproterozoic in the South-American continent: Diversity in the geologic time. Journal of South America Earth Sciences, 32:270-286.

Brito Neves B.B., Fuck R.A. 2013. The Neoproterozoic evolution of the basement of the South-American platform. Journal of South American Earth Science, 47:72-89.

Brito Neves B.B., Fuck R.A., Pimentel M.M. 2014. The Brasiliano collage in South America: a review A colagem Brasiliana na América do Sul: uma revisão. Brazilian Journal of Geology, 44(3):493-518.
Buiter S.J.H., Torsvik T.H. 2014. A review of Wilson Cycle plate margins: A role for mantle plumes in continental break-up along sutures? Gondwana Research, 26:627-653.

Campanha G.A.C., Warren L., Boggiani P.C., Grohmann C.H., Cáceres A.A. 2010. Structural analysis of the Itapucumí Group in the Vallemí region, northern Paraguay: Evidence of a new Brasiliano/Pan-African mobile belt. Journal of South American Earth Sciences, 30:1-11.

Campos Neto M.C. 2000. Orogenic Systems from SouthwesternGondwana: an approach to Brasiliano-Pan African Cycle and orogenic collage in southeastern-Brazil. In:Cordani, U.G., Milani, E.J., Thomaz-Filho, A., Campos, D.A. (eds.) Tectonic Evolution of South America. p. 335-365.

Campos Neto. M.C. \& Figueiredo M.C.H. 1995. The Rio Doce Orogeny, southeastern Brazil. Journal of South American Earth Science, 8(2):143-162.

Chang H.K., Kowsmann R.O., Figueiredo A.M.F., Bender A.A. 1992 Tectonics and stratigraphy of the East Brazil Rift system: an overview. In: P.A. Ziegler (Editor), Geodynamics of Rifting, Volume II. Case History Studies on Rifts: North and South America and Africa. Tectonophysics, 213:97-138

Corti G., Bonini M., Conticelli S., Innocenti F., Manetti P., Sokoutis D. 2003. Analogue modelling of continental extension: a review focused on the relations between the patterns of deformation and the presence of magma. Earth-Science Reviews, 63:169-247.

Corti G., Bonini M., Mazzarini F., Boccaletti M., Innocenti F., Manetti P. Mulugeta G., Sokoutis. D. 2002. Magma-induced strain localization in centrifuge models of transfer zones.Tectonophysics, 348:205-218.

De Carvalho H., Tassinari C., Alves P.H., Guimarães F., Simões M.C. 2000. Geochronological review of the Precambrian in West Angola: links with Brazil. Journal of African Earth Sciences, 31;383-402.

Delhal J., Ledent D., Cordani U.G. 1969. Ages Pb/U, Sr/Rb et Ar/K de Formations Métamorphiques et Granitiques du Sud-Est du Brésil (États de Rio de Janeiro et Minas Gerais). Annales de la Société Géologique de Belgique, 92:271-283.

Delor C., Lafon J.M., Rossi P., Cage M., Pato D., Chevrel S., Lê Metour J., Matukov. D., Sergeev S. 2006. Unravelling precambrian crustal growth of Central West Angola: Neoarchean to Siderian inheritance main Osirian accretion and discovery of the "Angolan" Panafrican Belt. In: $21^{\text {st }}$ Colloquium of African Geology, Mocambique. Abstract Book, 40-41.

De Waele B., Johnson S.P, Pisarevsky S.A. 2008. Palaeoproterozoic to Neoproterozoic growth and evolution of the eastern Congo Craton: Its role in the Rodinia puzzle. Precambrian Research, 160:127-141

Ebert H. 1957. Beitrag zur Gliederung des Präkambriums in Minas Gerais. Geol. Rdsch., Stuttgart, 45(3):471-521.

Ebinger C. 2005. Continental breakup: the East African perspective. Astronomy and Geophysics, 46:2.16-2.21

Fernandez-Alonso M., Cutten H., De Waele B., Tack L., Tahona A. Baudeta D., Barritt S.D. 2012. The Mesoproterozoic KaragweAnkole Belt (formerly the NE Kibara Belt): The result of prolonged extensional intracratonic basin development punctuated by two short-lived far-field compressional events. Precambrian Research, 216-219:63-86

Fernandes G.L., Schmitt R.S., Bongiolo E., Mendes J.C., Basei M.A.S. 2015. Unraveling the tectonic evolution of a NeoproterozoicCambrian active margin in the Ribeira Orogen (SE Brazil): U-Pb and Lu-Hf provenance data. Precambrian Research, 266:337-360. 
Fonseca A.C. 1993. Esboço geocronológico da região de Cabo Frio, Estado do Rio de Janeiro. PhD Thesis, University of São Paulo, Brazil.

Fonseca M.J.G., Heilbron M., Chrispim S. 1984. Geologia estrutural da área de Cabo Frio e Armação dos Búzios. In: SBG, Congresso Brasileiro Geologia, 33, Rio de Janeiro, Anais... Vol XII, p.5393 - 5424.

Fonseca M.J.G., Mendes J.C., Silvam Z.C.G., Moura J.C. 2012. Zona de sutura e organização do Orógeno Ribeira Setentrional. Brazilian Journal of Geology, 42(4):812-823.

Fonseca M.J.G., Silva Z.C,G, Campos D.A., Tosatto P. 1979. Folhas do Rio de Janeiro, Vitória e Iguape. Texto explicativo e Mapa. DNPM, Brasília, 239 p.

Geraldes M.C., Heilbron M., Pascutti A.H.F.G., Silva T.M., Meneses P.T., Valladares C.S., Almeida J.C.H., Duarte B.P., Tupinambá M., Nogueira J.R., Valeriano C., Silva L.G.E., Schmitt R.S., Ragatky C.D., Nummer A.R., Valente S.C., Dios F.B., Pamplona M.D., Silva M., Saliba F., Mello F.M., Palermo N., Mello R.P., Guimarães P.V., Silva F.L, 2009. Mapa Geológico da Folha Casemiro de Abreu SF.23-Z-B-III. Belo Horizonte: CPRM, CD-ROM.

Geraldes M.C., Motoki A., Costa A., Mota C.E., Mohriak W.U. 2013. Geochronology (Ar/Ar and $\mathrm{K}-\mathrm{Ar}$ ) of the South Atlantic post-breakup magmatism. In: Mohriak W.U., Danforth A., Post P.J., Brown D.E., Tari G.C., Nemc`ok M., Sinha S.T. (eds). Conjugate Divergent Margins. Geological Society, London, Special Publications, 369:41-74.

Guedes E., Heilbron M., Vasconcelos P.M., Valeriano C.M., Almeida J.C.H., Teixeira W., Thomaz Filho A. 2005. K/Ar and 40Ar/39Ar ages of dykes emplaced in the on-shore basement of the Santos Basin, Resende area, SE Brazil: implications for the south Atlantic opening and Tertiary reactivation. Journal of South American Earth Sciences, 18:371-182.

Guiraud M., Buta-Neto A., Quesne D. 2010. Segmentation and differential post-rift uplift at the Angola margin as recorded by the transform-rifted Benguela and oblique-to-orthogonal-rifted Kwanza basins. Marine and Petroleum Geology, 27:1040-1068.

Heilbron M., Chrispim S.J., Alves R.P., Simões L.S.A. 1982. Geologia do Cabo de Búzios (Estado do Rio de Janeiro). Anais da Academia Brasileira de Ciências, 54 (3): 553-562.

Heilbron M., Duarte B.P., Valeriano C.M., Simonetti A., Machado N., Nogueira J.R. 2010. Evolution of reworked Paleoproterozoic basement rocks within the Ribeira belt (Neoproterozoic), SE-Brazil, based on U-Pb geochronology: Implications for paleogeographic reconstructions of the São Francisco-Congo paleocontinent. Precambrian Research, 178: 136-148.

Heilbron M. \& Machado N. 2003. Timing of terrane accretion in the Neoproterozoic-Eopaleozoic Ribeira belt SE Brazil. Precambrian Research, 125:87-112.

Heilbron M., Mohriak W.U., Valeriano C.M., Milani E.J., Almeida J., Tupinambá M. 2000. From collision to extension: The roots of the southeastern continental margin of Brazil. In: Mohriak W.U. \& Talwani M. (eds). Atlantic Rifts and continental margins Geophysical Monograph 115. American Geophysical Union. p. 1-32.

Heilbron M., Tupinambá M., Valeriano C.M., Armstrong R., Silva L.G.E., Melo R.S., Machado A.S.N. 2013. The Serra da Bolívia Complex: the record of a new Neo-proterozoic arc-related unit at Ribeira Belt. Precambrian Research, 238:158-175.

Heilbron M., Valeriano C.M., Tassinari C.C.G., Almeida J.C.H., Tupinambá M., Siga Jr. O., Trouw R.A.J. 2008. Correlation of Neoproterozoic terranes between theRibeira Belt. SE Brazil and its African counterpart: comparative tectonic evolution and open questions. In: Pankhurst R.J., Trouw R.A.J., Brito Neves B.B., De Wit M.J. (eds.), West Gondwana Pre-Cenozoic Correlations Across the SouthAtlantic Region. Geological Society, London, Special Publications, 294, 279-296.
Kröner A., Rojas-Agramonte Y., Hegner E., Hoffman K.-H., Wingate M.T.D. 2010. SHRIMP zircon dating and $\mathrm{Nd}$ isotopic systematics of Paleoproterozoic migmatitiv orthogneisses in the Epupa Metamorphic Complex of northwest Namibia. Precambrian Research, 183: 50-69.

Kuhn A., Stuwe K., Trouw R.A.J. 2004. Metamorphic Evolution of the Ribeira Belt: Evidence from Outcrops in the Rio de Janeiro Area, Brazil. Journal of Petrology, 43:2303-2323.

Leonardos Jr. O.H., Fyfe W.S. 1974. Ultrametamorphism and melting of a continental margin: The Rio de Janeiro Region, Brazil. Contributions to Mineralogy and Petrology, 46:201-214.

Machado R., Demange M. 1990. Reinterpretação estrutural e tectônica da região leste da Baía da Guanabara e a definição do Batólito de Araruama (RJ). In: SBG, Congresso Brasileiro Geologia, 36, Natal (RN), Anais... 2744-2754.

Machado N., Valladares C., Heilbron M., Valeriano C. 1996. U-Pb geochronology of the central Ribeira belt (Brazil) ans implications for the evolution of the Brazilian Orogeny. Precambrian Research, 79: 347-361.

Manatschal G. \& Müntener O. 2009. A type sequence across an ancient magma-poor ocean-continent transition: the example of the western Alpine Tethys ophiolites. Tectonophysics, 473(1-2):4-19.

Manatschal G., Müntener O., Lavier L.L., Minshull T.A., PéronPinvidic G. 2007 Observations from the Alpine Tethys and IberiaNewfoundland margins pertinent to the interpretation of continental breakup. In: Karner G.D., Manatschal G., Pinheiro L. M. (eds.) Imaging, Mapping and Modelling ContinentalLithosphere Extension and Breakup. Geological Society, London, Special Publications, 282, 291-324.

McCourt S., Armstrong R.A., Jelsma H., Mapeo R.B.M. 2013. New U-Pb SHRIMP ages from the Lubango region, SW Angola: insights into the Paleoproterozoic evolution of the Angolan Shield, southern Congo Craton, Africa. Journal of the Geological Society of London, 170: 353-363.

Meisling K., Cobbold P.R., Mount V.S. 2001. Segmentation of an obliquely rifted margin, Campos and Santos Basins, southeastern Brazil. American Association of Petroleum Geologists Bulletin, 85:1903-1924

Mendes J.C., Schmitt R.S., Penha H.M., Ludka I.P., Dantas, E. L. 2006. Calc-alkaline magmatism in a low pressure high temperature Neoproterozoic terrane, SE Brazil: new U-Pb data. In: V Simposio Sudamericano de Geologia Isotopica, 2006, Punta del Este. Short papers of the V SSAGI, 2006. v. 1. p. 123-125.

Miller R.McG., Frimmel H.E., Will T.M. 2009. Geodynamic synthesis of the Damara Orogen sensu lato. Neoproterozoic to Early Palaeozoic evolution of Southwestern Africa. In: Gaucher, C., Sial, A.N., Halverson, G.P., Frimmel, H.E. (eds.), Neoproterozoic-Cambrian Tectonics, Global Change and Evolution: A Focus on Southwestern Gondwana: Developments in Precambrian Geology, 16. Elsevier, 231-235.

Mohriak W.U., Barros A.Z. 1990. Novas evidências de tectonismo cenozóico na região sudeste do Brasil: o gráben de Barra de São João na plataforma continental de Cabo Frio, Rio de Janeiro. Revista Brasileira de Geociências, 20(1-4):187-196.

Monié P., Bosch D., Bruguier O., Vauchez A., Rolland Y., Nsungani P., Buta Neto A. 2012. The Late Neoproterozoic/Early Palaeozoic evolution of the West Congo Belt of NW Angola: geochronological (U-Pb and Ar-Ar) and petrostructural constraints. Terra Nova, 24(3):238-247

Moraes J.M. 2009. Geologia do Granito Silva Jardim (RJ): Implicações na evolução tectônica dos Terrenos Oriental e Cabo Frio. Master Thesis UERJ. 65 p. 
Moulin M., Aslanian D., Unternehr P. 2010. A new starting point for the South and Equatorial Atlantic Ocean. Earth-Science Reviews, 98:1-37.

Noce C.M., Pedrosa-Soares A.C., Silva L.C. da, Armstrong R.A., Piuzana D. 2007. Evolution of polycyclic basement complexes in the Araçuaí Orogen, based on U-Pb SHRIMP data: Implications for Brazil-Africa links in Paleoproterozoic time. Precambrian Research, 159:60-78.

Nurnberg D., Müller R.D. 1991. The tectonic evolution of the South Atlantic from Late Jurassic to present. Tectonophysics, 191:27-53.

Oliveira J.P., Borghi L., Aristizábal C.I.O., Perosi F. The onshore encroachment of the Cretaceous in the Paraíba do Sul river delta comples (Campo Basin, Brazil). Submitted to Marine and Petroleum Geology.

Pedrosa-Soares A.C. \& Alkmim F.F. 2011. How many rifting events preceded the development of the Araçuaí-West Congo orogen? Geonomos, 19:244-251.

Pedrosa-Soares A.C., Vidal P., Leonardos O.H., De Brito-Neves B.B. 1998. Neoproterozoic oceanic remnants in eastern Brazil: further evidence and refutation of an exclusively ensialic evolution for the Aracuai-west Congo orogen. Geology, 26:519-522.

Peixoto C.A. \& Heilbron M. 2010. Geologia da Klippe Italva na Região entre Cantagaloe Italva, Noroeste do Estado do Rio de Janeiro. Geociências (UNESP), 3:277-289.

Péron-Pinvidic G. \& Manatschal G. 2010. From microcontinents to extensional allochthons: witnesses of how continents rift and break apart? Petroleum Geoscience, 16:189-197.

Rabinowitz P.D. \& La Brecque J. 1979. The Mesozoic South Atlantic Ocean and the evolution of its continental margins. Journal of Geophysical Research, 84:5973-6002.

Ricominni C., Sant'Anna L.G., Ferrari A.L. 2004. Evolução geológica do rifte Continental do Sudeste do Brasil. In: Mantesso Neto V., Bartorelli A., Carneiro C.D.R, Brito Neves B.B. (eds.). Geologia do Continente Sul-Americano: evolução da obra de Fernando Flávio Marques de Almeida. Ed. Beca, São Paulo, Brasil, 647 p.

Rosier G.F. 1957. A geologia da Serra do Mar, entre os picos de Maria Comprida e do Desengano (Estado do Rio de Janeiro), DNPM-DGM, Boletim 116: 58 p.

Rosier G.F. 1965. Pesquisas geológicas na parte oriental do Estado do Rio de Janeiro e na parte vizinha de Minas Gerais, DNPM, Div. Geol. Min., Rio de Janeiro (RJ). Boletim, 222:1-40.

Schmitt R.S. \& Armstrong R. 2014. Unraveling the tectonic evolution of Brasiliano orogens from the actual South Atlantic margins - new $\mathrm{U}-\mathrm{Pb}$ data. In: $9^{\text {th }}$ South American Symposium on Isotope Geology. Program and Abstracts, $91 \mathrm{p}$.

Schmitt R.S., Mendes J.C., Peternel R., Silva L.C., Dantas E.L. $2012 a$. Dating high grade syn-orogenic plutons and supracrustal rocks in a hot orogen - Ribeira belt case-study. In: SSAGI, Medellin, Colombia.

Schmitt R.S., Mansur K.L., Guerra J.V., Góes N.F.B., Silva R.S., Ramos A.S., Machado G.M.F., Savi D.C., Geraldes M.C., Medeiros S.R., Moraes J.M., Silva C.B., Matta P.B., Toledo P.P., Motoki A., Sichel S., Guimarães P.V., Silva F.L., Palermo N., Pereira R.M., Meneses P.T. 2009a. Mapa Geológico da Folha Cabo Frio SF.23-Z-B-VI. Belo Horizonte: CPRM, CD-ROM.

Schmitt R.S., Mohriak W., Mansur K.L., Skrepnek C.C., Trouw R.A.J., Guerra J.V., Silva R.S., Ramos A.S., Stanton N., Almeida J.C.H., Heilbron M., Motoki A., Sichel S., Guimarães P.V., Palermo N., Silva F.L., Pereira R.M., Meneses P.T. 2009b. Mapa Geológico da Folha Rio das Ostras SF.24-Y-A-IV. Belo Horizonte: CPRM, CD-ROM.

Schmitt R.S. \& Trouw R.A.J. 1997. Estudo preliminar dos indicadores de transporte tectônico pré-cambriano na Região dos Lagos, Rio de Janeiro. In: SBG, Simpósio Geol. Sudeste, 5, Penedo (RJ). Atas... 1:142-144
Schmitt R.S., Trouw, R.A.J., Medeiros S.R., Dantas E.L. 2008a. Age and geotectonic setting of Late-Neoproterozoic juvenile mafic gneisses and associated paragneisses from the Ribeira Belt (SE Brazil): geochemistry and Sm-Nd data - implications on Gondwana assembly. Gondwana Research, 13:502-515.

Schmitt R.S., Trouw R.A.J., Passchier C.W., Medeiros S.R., Armstrong R.A. 2012b. 530 Ma syntectonic syenites and granites in NW Namibia - Their relation with collision along the junction of the Damara and Kaoko belts. Gondwana Research, 21:362-377.

Schmitt R.S. Trouw R.A.J., Van Schmus W.R., Passchier C.W. 2008b. Cambrian orogeny in the Ribeira Belt (SE Brazil) and correlations within West Gondwana: ties that bind underwater. In: Pankhurst R.J. Trouw R.A.J., Brioto Neves B.B., De Wit M.J. (eds.) West Gondwana: PreCenozoic Correlations across the South Atlantic Region. Geological Society, London, Special Publications, 294:279-296.

Schmitt R.S., Trouw R.A.J., Van Schmus W.R., Pimentel M.M. 2004. Late amalgamation in the central part of West Gondwana: new geochronological data and the characterization of a Cambrian collisional orogeny in the Ribeira Belt (SE Brazil). Precambrian Research, 133:29-61.

Scotchman I.C., Gilchrist G., Kusznir N.J., Roberts A.M., Fletcher R. 2010. The breakup of the South Atlantic Ocean: formation of failed spreading axes and blocks of thinned continental crust in the Santos Basin, Brazil and its consequences for petroleum system development. In: Vining B.A., Pickering S.C. (eds). Petroleum Geology: From Mature Basins to New Frontiers - Proceedings of the $7^{\text {th }}$ Petroleum Geology Conference, 855-866. DOI: 10.1144/0070855.

Seth B., Kröner A., Mezger K., Nemchin A.A., Pidgeon R.T., Okrusch M. 1998. Archean to Neoproterozoic magmatic events in the Kaoko belt of NW Namibia and their geodynamic significance. Precambrian Research, 92:341-363.

Seth B., Armstrong R.A., Brandt S., Villa I., Kramers J.D. 2003. Mesoproterozoic $\mathrm{U}-\mathrm{Pb}$ and $\mathrm{Pb}-\mathrm{Pb}$ ages of granulites in NW Namibia: reconstructing a complete orogenic cycle. Precambrian Research, 126:147-168.

Silva L.C., McNaughton N.J., Hartmann L.A., Fletcher I.R. 2003. Zircon U-Pb SHRIMP dating of the Serra dos Órgãos and Rio de Janeiro gneissic granitic suites: implications for the $(560 \mathrm{Ma})$ Brasiliano/Pan-African Collage. Revista Brasileira de Geociências, 33:237-244

Silva L.C., Pedrosa-Soares A.C., Teixeira, L.R.R., Armstrong R. 2008. Tonian rift-related, A-type continental plutonism in the Araçuaí Orogen, eastern Brazil: New evidence for the breakup stage of the São Francisco-Congo Paleocontinent. Gondwana Research, 13:527-537.

Souza P.C.M. 2011. Análise cinemática e dinâmica do sistema de falhas cenozóicas ENE-WSW do entorno da Lagoa de Araruama (RJ). Master Thesis, Federal University of Rio de Janeiro. 139 p.

Stanton N., Ponte-Neto C., Masini E., Bijani R., Fontes S., Flexor J.M. 2014. A Geophysical View of the Southeastern Brazilian Margin at Santos Basin. Journal of South American Earth Sciences, 55:141-154.

Stanton N. \& Schmitt R. 2015. Onshore-offshore prolongation of structures between Campos and Santos Basins from aeromagnetic data. $14^{\text {th }}$ International Congress of the Brazilian Geophysical Society, Expanded abstracts

Stanton N., Schmitt R.S., Galdeano A., Maia M., Mane M. 2010. Crustal Structure of the Southeastern Brazilian Margin, Campos Basin, from Aeromagnetic Data: New kinematic constraints. Tectonophysics, 490:15-27.

Stanton N., Schmitt R.S., Skrepnek C.C., Guerra J.V., Menino G.I. 2005. Evolução tectônica do Alto do cabo Frio - Ilhas oceânicas e região costeira adjacentes RJ: Dados estruturais preliminares. In: $9^{\circ}$ Simpósio de Geologia do Sudeste, 2005, Niterói. Abstracts. v. 1. p. 185-185. 
Tack L., Wingate M.T.D., Liegeois J.P., Fernandez-Alonso M., Deblond A. 2001. Early Neoproterozoic magmatism (1000 - $910 \mathrm{Ma})$ of the Zadinian and Mayumbian Groups (Bas-Congo): onset of Rodinia rifting at the western edge of the Congo craton. Precambrian Research, 110:277-306.

Teixeira W., Ávila C.A., Dussin I.A., Corrêa Neto A.V., Bongiolo E.M., Santos J.O., Barbosa N.S. 2015.A juvenile accretion episode (2.35 $2.32 \mathrm{Ga}$ ) in the Mineiro belt andits role to the Minas accretionary orogeny: Zircon $\mathrm{U}-\mathrm{Pb}-\mathrm{Hf}$ andgeochemical evidences. Precambrian Research, 256:148-169.

Tetzner W., Camillo E.J.R., Almeida J.C.H., 2001. Tectônica Mesozóica e emplacement dos diques básicos do Cabo de Búzios, RJ: Boletim de Resumos do VII Simpósio de Geologia do Sudeste, SBG-RJ, Rio de Janeiro, 91-92

Thomaz-Filho A., Mizusaki A.M.P., Milani E.J., Cesero P. 2000. Rifting and Magmatism Associated with the South América and África Break Up. Revista Brasileira de Geociências, 30(1):017-019.

Tommasi A., Vauchez A. 2001. Continental rifting parallel to ancient collisional belts: an efect of the mechanical anisotropy of the lithospheric mantle. Earth and Planetary Sciences Letters, 185:199-210.

Trompette R. 1994. Geology of Western Gondwana (2000 - 500 Ma).A.A. Balkema Rotterdam, 350 pp.

Trouw R.A.J., Heilbron M., Ribeiro A., Paciullo F., Valeriano C., Almeida J.C.H., Tupinambá M., Andreis R.R. 2000. The central segment of the Ribeira belt. In: Cordani U.G., Milani E.J., Thomaz-Filho A., Campos D.A. (eds.). Tectonic Evolution of South America. $31^{\text {st }}$ International Geological Congress, Rio de Janeiro, Brazil, pp. 287-310.

Trouw R.A.J., Peternel R., Ribeiro A., Heilbron M., Vinagre R., Duffles P., Trouw C.C., Fontainha M., Kussama H.H. 2013. A new interpretation for the interference zone between the southern Brasília Belt and the central Ribeira Belt, SE Brazil. Journal of South American Earth Sciences, 48:43-57.

Tupinambá M., Heilbron M., Duarte B.P., Almeida J.C.H., Valladares C.S., Pacheco B.T., Salomão M.S., Conceição F.R., Eirado da Silva L.G., Almeida C.G., Ferrassoli M.A., Costa M.C. O., Tupinambá L.R., Rocha D.S., Benac P.M., Silva H.M.O.C., Guimarães P.V., Silva F.L., Palermo N., Pereira R.M., Meneses P.T., Mane M. 2009. Mapa Geológico da Folha Nova Friburgo SF.23-Z-B-II. Belo Horizonte: CPRM, CD-ROM.

Tupinambá M., Heilbron M., Duarte B.P., Nogueira J.R., Valladares C., Almeida J.C.H., Eirado-Silva L.G.E., Medeiros S.R., Almeida C.G., Miranda A., Ragatky C.D., Mendes J.C., Ludka I. 2007. Geologia da Faixa Ribeira Setentrional: Estado da Arte e Conexões com a Faixa Araçuaí. Geonomos, 15:67-79.

Tupinambá M., Heilbron M., Valeriano C., Porto Jr. R., Dios F.B., Machado M., Silva L.G.E., Almeida J.C.H. 2012. Juvenile contribution of Neoproterozoic Rio Negro Magmatic Arc (Ribeira Belt, Brazil): implications for Western Gondwana amalgamation. Gondwana Research, 21:422-438.
Tupinambá M., Machado N., Heilbron M., Ragatky C.D. 2007b. Meso-Neoproterozoic lithospheric extensional events in the São Francisco Craton and its Surrounding South American and African metamorphic belts. Revista Brasileira de Geociências, 37:87-91.

Tupinambá M., Teixeira W., Heilbron M. 2000. Neoproterozoic western Gondwana assembly and subduction-related plutonism: the role of the Rio Negro Complex in the Ribeira Belt. Revista Brasileira de Geociências, 30:7-11.

Turner S., Regelous M., Kelley S., Hawkesworth C., Mantovani M. 1994. Magmatism and continental break-up in the South Atlantic: High precision 40Ar/39Ar geochronology. Earth and Planetary Science Letters, 121:333-348.

Valente S.C., Corval A., Duarte B.P., Ellam R.M., Fallick A.E., Meighan I.G., Dutra T., 2007. Tectonic boundaries, crustal weakness zones and plume-subcontinental lithospheric mantle interactions in the Serra do Mar dyke swarm, SE Brazil. Revista Brasileira de Geociências, 3(1):194-201.

Valeriano C.M., Pimentel M.M., Heilbron M., Almeida J.C.H., Trouw R.A.J. 2008. Tectonic evolution of the Brasília Belt, Central Brazil, and early assembly of Gondwana. In: Pankhurst R.J., Trouw R.A.J., Brioto Neves B.B., De Wit M.J. (eds.) West Gondwana: Pre-Cenozoic Correlations across the South Atlantic Region. Geological Society, London, Special Publications, 294:197-210.

Valeriano C.M., Tupinambá M., Simonetti A., Heilbron M., Almeida J.C.H., Eirado L.G. 2011. U-Pb LA-MC-ICPMS geochronology of Cambro-Ordovician post-collisional granites of the Ribeira belt, southeast Brazil: terminal Brasiliano magmatism in central Gondwana supercontinent. Journal of South American Earth Sciences, 32:415-428.

Valladares C.S., Machado N., Heilbron M., Duarte B.P., Gauthier G. 2008. Sedimentary provenance in the Central Ribeira Belt based on laser-ablation ICPMS207Pb/206Pb zircon ages. Gondwana Research, 13:516-526.

Viana S.M., Valladares C.S., Duarte B.P. 2008. Geoquímica dos ortognaisses do Complexo Região dos Lagos, Araruama-Cabo Frio, Rio de Janeiro, Brasil. Revista Brasileira de Geociências, 27(1):111-120.

Wood D.A. 1980. The application of a Th-Hf-Ta diagram to problems of tectonomagmatic classification and to establishing the nature of crustal contamination of basaltic lavas of the British Tertiary Volcanic Province. Earth and Planetary Science Letters, 50(1):11-30.

Zalán P.V. \& Oliveira J.A.B. 2005. Origem e evolução estrutural do Sistema de Riftes Cenozóicos do Sudeste do Brasil. Boletim de Geociências da Petrobras, 13(2):269-300.

Zimbres E., Kawashita K., Van Schmus W.R., 1990. Evidências de um núcleo Transamazônico na Região de Cabo Frio, RJ e sua correlação com o cráton de Angola, Africa. Congresso Brasileiro de Geologia, 36, Sociedade Brasileira de Geologia. Natal, Brazil, pp. 2735-2743.

Available at www.sbgeo.org.br 
Appendix I. Compilation of geochronological data from the Cabo Frio Tectonic Domain.

\begin{tabular}{|c|c|c|c|c|c|c|c|c|}
\hline Geological Unit & Lithotype & Location & Method & Technique & $\begin{array}{l}\text { Age } \\
\text { (Ma) }\end{array}$ & Error & Interpretation & Reference \\
\hline $\begin{array}{l}\text { Regiao dos Lagos } \\
\text { Complex }\end{array}$ & Orthogneiss & $\begin{array}{c}\text { Ponta do } \\
\text { Marisco - Buzios }\end{array}$ & Sm-Nd & WR - TDM & 2700 & 270 & $\begin{array}{l}\text { Mixing age } \\
\text { of magmatic } \\
\text { source }\end{array}$ & $\begin{array}{c}\text { Fonseca A.C. } \\
\text { (1993) }\end{array}$ \\
\hline $\begin{array}{l}\text { Regiao dos Lagos } \\
\text { Complex }\end{array}$ & Orthogneiss & $\begin{array}{c}\text { Conchas beach - } \\
\text { Cabo Frio }\end{array}$ & Sm-Nd & WR - TDM & 2600 & 260 & $\begin{array}{l}\text { Mixing age } \\
\text { of magmatic } \\
\text { source }\end{array}$ & $\begin{array}{c}\text { Fonseca A.C. } \\
(1993)\end{array}$ \\
\hline $\begin{array}{l}\text { Regiao dos Lagos } \\
\text { Complex }\end{array}$ & Orthogneiss & $\begin{array}{l}\text { Praia da } \\
\text { Caravela }\end{array}$ & Sm-Nd & WR - TDM & 2600 & 260 & $\begin{array}{l}\text { Mixing age } \\
\text { of magmatic } \\
\text { source }\end{array}$ & $\begin{array}{c}\text { Fonseca A.C. } \\
(1993)\end{array}$ \\
\hline $\begin{array}{l}\text { Regiao dos Lagos } \\
\text { Complex }\end{array}$ & Orthogneiss & $\begin{array}{c}\text { Ponta do } \\
\text { Marisco - Buzios }\end{array}$ & Sm-Nd & WR - TDM & 2500 & 250 & $\begin{array}{l}\text { Mixing age } \\
\text { of magmatic } \\
\text { source }\end{array}$ & $\begin{array}{c}\text { Fonseca A.C. } \\
\text { (1993) }\end{array}$ \\
\hline $\begin{array}{l}\text { Regiao dos Lagos } \\
\text { Complex }\end{array}$ & Orthogneiss & $\begin{array}{c}\text { Ponta do } \\
\text { Marisco - Buzios }\end{array}$ & Sm-Nd & WR - TDM & 2500 & 250 & $\begin{array}{l}\text { Mixing age } \\
\text { of magmatic } \\
\text { source }\end{array}$ & $\begin{array}{c}\text { Fonseca A.C. } \\
(1993)\end{array}$ \\
\hline $\begin{array}{l}\text { Regiao dos Lagos } \\
\text { Complex }\end{array}$ & Orthogneiss & $\begin{array}{c}\text { Conchas beach - } \\
\text { Cabo Frio }\end{array}$ & Sm-Nd & WR - TDM & 2500 & 250 & $\begin{array}{l}\text { Mixing age } \\
\text { of magmatic } \\
\text { source }\end{array}$ & $\begin{array}{c}\text { Fonseca A.C. } \\
(1993)\end{array}$ \\
\hline $\begin{array}{l}\text { Regiao dos Lagos } \\
\text { Complex }\end{array}$ & Orthogneiss & $\begin{array}{c}\text { Conchas beach - } \\
\text { Cabo Frio }\end{array}$ & Sm-Nd & WR - TDM & 2500 & 250 & $\begin{array}{l}\text { Mixing age } \\
\text { of magmatic } \\
\text { source }\end{array}$ & $\begin{array}{c}\text { Fonseca A.C. } \\
\text { (1993) }\end{array}$ \\
\hline $\begin{array}{l}\text { Regiao dos Lagos } \\
\text { Complex }\end{array}$ & Orthogneiss & Arraial do Cabo & Sm-Nd & WR - TDM & 2500 & 250 & $\begin{array}{l}\text { Mixing age } \\
\text { of magmatic } \\
\text { source }\end{array}$ & $\begin{array}{c}\text { Fonseca A.C. } \\
\text { (1993) }\end{array}$ \\
\hline $\begin{array}{l}\text { Regiao dos Lagos } \\
\text { Complex }\end{array}$ & Orthogneiss & $\begin{array}{c}\text { Ponta do } \\
\text { Marisco - Buzios }\end{array}$ & Sm-Nd & WR - TDM & 2450 & 245 & $\begin{array}{l}\text { Mixing age } \\
\text { of magmatic } \\
\text { source }\end{array}$ & $\begin{array}{c}\text { Fonseca A.C. } \\
(1993)\end{array}$ \\
\hline $\begin{array}{l}\text { Regiao dos Lagos } \\
\text { Complex }\end{array}$ & Orthogneiss & $\begin{array}{c}\text { Ponta do } \\
\text { Marisco - Buzios }\end{array}$ & Sm-Nd & WR - TDM & 2450 & 245 & $\begin{array}{l}\text { Mixing age } \\
\text { of magmatic } \\
\text { source }\end{array}$ & $\begin{array}{c}\text { Fonseca A.C. } \\
(1993)\end{array}$ \\
\hline $\begin{array}{l}\text { Regiao dos Lagos } \\
\text { Complex }\end{array}$ & Orthogneiss & $\begin{array}{c}\text { Conchas beach - } \\
\text { Cabo Frio }\end{array}$ & Sm-Nd & WR - TDM & 2400 & 240 & $\begin{array}{c}\text { Mixing age } \\
\text { of magmatic } \\
\text { source }\end{array}$ & $\begin{array}{c}\text { Fonseca A.C. } \\
(1993)\end{array}$ \\
\hline $\begin{array}{l}\text { Regiao dos Lagos } \\
\text { Complex }\end{array}$ & Orthogneiss & $\begin{array}{l}\text { São Pedro } \\
\text { D’Aldeia }\end{array}$ & $\mathrm{Rb}-\mathrm{Sr}$ & ISOCHRON & 1923 & 60 & $\begin{array}{l}\text { Crystallisation } \\
\text { age }\end{array}$ & $\begin{array}{l}\text { Delhal et al. } \\
\qquad(1969)\end{array}$ \\
\hline $\begin{array}{l}\text { Regiao dos Lagos } \\
\text { Complex }\end{array}$ & Orthogneiss & $\begin{array}{c}\text { Ponta do } \\
\text { Marisco - Buzios }\end{array}$ & $\mathrm{Rb}-\mathrm{Sr}$ & $\begin{array}{l}\text { ISOCHRON } \\
\quad(\mathrm{N}=4)\end{array}$ & 2071 & 75 & $\begin{array}{l}\text { Crystallisation } \\
\text { age }\end{array}$ & $\begin{array}{c}\text { Fonseca A.C. } \\
(1993)\end{array}$ \\
\hline Buzios Succession & Orthoamphibolite & $\begin{array}{c}\text { Emerencias } \\
\text { Range }\end{array}$ & Sm-Nd & WR-TDM & 2040 & 204 & $\begin{array}{c}\text { Mixing age } \\
\text { of magmatic } \\
\text { sources }\end{array}$ & $\begin{array}{c}\text { Schmitt et al. } \\
\text { (2008b) }\end{array}$ \\
\hline $\begin{array}{l}\text { Regiao dos Lagos } \\
\text { Complex }\end{array}$ & Orthogneiss & $\begin{array}{l}\text { São Pedro } \\
\text { D’Aldeia }\end{array}$ & $\mathrm{U}-\mathrm{Pb}$ & TIMS (UI) & 1981 & 18 & $\begin{array}{c}\text { Crystallisation } \\
\text { age }\end{array}$ & $\begin{array}{c}\text { Zimbres et al. } \\
\text { (1990) }\end{array}$ \\
\hline $\begin{array}{l}\text { Regiao dos Lagos } \\
\text { Complex }\end{array}$ & Orthogneiss & Rio das Ostras & $\mathrm{U}-\mathrm{Pb}$ & TIMS (UI) & 1977 & 9 & $\begin{array}{c}\text { Crystallisation } \\
\text { age }\end{array}$ & $\begin{array}{l}\text { Schmitt et al. } \\
\qquad(2004)\end{array}$ \\
\hline $\begin{array}{l}\text { Regiao dos Lagos } \\
\text { Complex }\end{array}$ & Orthogneiss & $\begin{array}{c}\text { Conchas beach - } \\
\text { Cabo Frio }\end{array}$ & $\mathrm{U}-\mathrm{Pb}$ & TIMS (UI) & 1975 & 7 & $\begin{array}{c}\text { Crystallisation } \\
\text { age }\end{array}$ & $\begin{array}{c}\text { Schmitt et al. } \\
\text { (2008b) }\end{array}$ \\
\hline $\begin{array}{l}\text { Regiao dos Lagos } \\
\text { Complex }\end{array}$ & Orthogneiss & Rio das Ostras & $\mathrm{U}-\mathrm{Pb}$ & TIMS (UI) & 1971 & 5 & $\begin{array}{c}\text { Crystallisation } \\
\text { age }\end{array}$ & $\begin{array}{c}\text { Schmitt et al. } \\
(2004)\end{array}$ \\
\hline
\end{tabular}


Appendix I. Continuation.

\begin{tabular}{|c|c|c|c|c|c|c|c|c|}
\hline Geological Unit & Lithotype & Location & Method & Technique & $\begin{array}{l}\text { Age } \\
(\mathrm{Ma})\end{array}$ & Error & Interpretation & Reference \\
\hline Buzios Succession & Orthoamphibolite & $\begin{array}{c}\text { Forte de São } \\
\text { Mateus, Cabo } \\
\text { Frio }\end{array}$ & $\mathrm{U}-\mathrm{Pb}$ & TIMS (UI) & 1969 & 5 & Inheritance & $\begin{array}{c}\text { Schmitt et al. } \\
\text { (2004) }\end{array}$ \\
\hline $\begin{array}{l}\text { Regiao dos Lagos } \\
\text { Complex }\end{array}$ & Orthogneiss & Macaé city & $\mathrm{U}-\mathrm{Pb}$ & TIMS (UI) & 1960 & 6 & $\begin{array}{c}\text { Crystallisation } \\
\text { age }\end{array}$ & $\begin{array}{c}\text { Schmitt et al. } \\
\text { (2004) }\end{array}$ \\
\hline Buzios Succession & Orthoamphibolite & $\begin{array}{l}\text { Geribá beach } \\
\text { (Buzios) }\end{array}$ & Sm-Nd & WR-TDM & 1960 & 196 & $\begin{array}{c}\text { Mixing age } \\
\text { of magmatic } \\
\text { sources }\end{array}$ & $\begin{array}{l}\text { Schmitt et al. } \\
\text { (2008b) }\end{array}$ \\
\hline $\begin{array}{l}\text { Regiao dos Lagos } \\
\text { Complex }\end{array}$ & Orthogneiss & $\begin{array}{l}\text { São Pedro } \\
\text { D'Aldeia }\end{array}$ & $\mathrm{Rb}-\mathrm{Sr}$ & $\begin{array}{l}\text { ISOCHRON } \\
(\mathrm{N}=5)\end{array}$ & 1800 & 62 & $\begin{array}{c}\text { Crystallisation } \\
\text { age }\end{array}$ & $\begin{array}{c}\text { Zimbres et al. } \\
\text { (1990) }\end{array}$ \\
\hline Buzios Succession & Paragneiss & $\begin{array}{l}\text { Lagoinha point } \\
\text { (Buzios) }\end{array}$ & Sm-Nd & WR-TDM & 1750 & 175 & $\begin{array}{l}\text { Mixing age of } \\
\text { sources }\end{array}$ & $\begin{array}{c}\text { Schmitt et al. } \\
\text { (2004) }\end{array}$ \\
\hline Buzios Succession & Paragneiss & $\begin{array}{c}\text { Tartaruga Beach } \\
\text { (Buzios) }\end{array}$ & Sm-Nd & WR-TDM & 1700 & 170 & $\begin{array}{l}\text { Mixing age of } \\
\text { sources }\end{array}$ & $\begin{array}{c}\text { Schmitt et al. } \\
\text { (2004) }\end{array}$ \\
\hline Buzios Succession & Paragneiss & $\begin{array}{l}\text { Lagoinha point } \\
\text { (Buzios) }\end{array}$ & Sm-Nd & WR-TDM & 1690 & 169 & $\begin{array}{c}\text { Mixing age of } \\
\text { sources }\end{array}$ & $\begin{array}{c}\text { Schmitt et al. } \\
\text { (2004) }\end{array}$ \\
\hline $\begin{array}{l}\text { Regiao dos Lagos } \\
\text { Complex }\end{array}$ & Orthogneiss & $\begin{array}{c}\text { Conchas beach - } \\
\text { Cabo Frio }\end{array}$ & $\mathrm{Rb}-\mathrm{Sr}$ & $\begin{array}{c}\text { ISOCHRON } \\
(\mathrm{N}=4)\end{array}$ & 1661 & 141 & $\begin{array}{c}\text { Crystallisation } \\
\text { age }\end{array}$ & $\begin{array}{c}\text { Fonseca A.C. } \\
\text { (1993) }\end{array}$ \\
\hline Buzios Succession & Paragneiss & $\begin{array}{l}\text { Forno Beach } \\
\text { (Buzios) }\end{array}$ & Sm-Nd & WR-TDM & 1650 & 165 & $\begin{array}{l}\text { Mixing age } \\
\text { of magmatic } \\
\text { source }\end{array}$ & $\begin{array}{c}\text { Fonseca A.C. } \\
\text { (1993) }\end{array}$ \\
\hline Buzios Succession & Orthoamphibolite & $\begin{array}{c}\text { Emerencias } \\
\text { Range }\end{array}$ & Sm-Nd & WR-TDM & 1610 & 161 & $\begin{array}{c}\text { Mixing age } \\
\text { of magmatic } \\
\text { sources }\end{array}$ & $\begin{array}{l}\text { Schmitt et al. } \\
\text { (2008b) }\end{array}$ \\
\hline Buzios Succession & Paragneiss & $\begin{array}{c}\text { Foca Beach } \\
\text { (Buzios) }\end{array}$ & Sm-Nd & WR-TDM & 1580 & 158 & $\begin{array}{l}\text { Mixing age of } \\
\text { sources }\end{array}$ & $\begin{array}{c}\text { Schmitt et al. } \\
\text { (2004) }\end{array}$ \\
\hline Buzios Succession & Paragneiss & $\begin{array}{c}\text { Ponta da } \\
\text { Lagoinha } \\
\text { (Buzios) }\end{array}$ & Sm-Nd & WR - TDM & 1450 & 145 & $\begin{array}{l}\text { Mixing age } \\
\text { of magmatic } \\
\text { source }\end{array}$ & $\begin{array}{c}\text { Fonseca A.C. } \\
\text { (1993) }\end{array}$ \\
\hline Buzios Succession & Paragneiss & $\begin{array}{l}\text { Forno Beach } \\
\text { (Buzios) }\end{array}$ & Sm-Nd & WR-TDM & 1450 & 145 & $\begin{array}{l}\text { Mixing age } \\
\text { of magmatic } \\
\text { source }\end{array}$ & $\begin{array}{c}\text { Fonseca A.C. } \\
\text { (1993) }\end{array}$ \\
\hline Buzios Succession & Orthoamphibolite & $\begin{array}{l}\text { Geribá beach } \\
\text { (Buzios) }\end{array}$ & Sm-Nd & WR-TDM & 1130 & 113 & $\begin{array}{c}\text { Mixing age } \\
\text { of magmatic } \\
\text { sources }\end{array}$ & $\begin{array}{l}\text { Schmitt et al. } \\
\text { (2008b) }\end{array}$ \\
\hline Buzios Succession & Orthoamphibolite & $\begin{array}{l}\text { Geribá beach } \\
\text { (Buzios) }\end{array}$ & Sm-Nd & WR-TDM & 1090 & 109 & $\begin{array}{l}\text { Mixing age } \\
\text { of magmatic } \\
\text { source }\end{array}$ & $\begin{array}{c}\text { Schmitt et al. } \\
\text { (2004) }\end{array}$ \\
\hline Palmital Succession & Amphibolite & Ponta Negra & Sm-Nd & WR-TDM & 1050 & 105 & $\begin{array}{l}\text { Mixing age } \\
\text { of magmatic } \\
\text { source }\end{array}$ & $\begin{array}{c}\text { Schmitt et al. } \\
\text { (2004) }\end{array}$ \\
\hline Buzios Succession & Amphibolite & $\begin{array}{l}\text { Geribá beach } \\
\text { (Buzios) }\end{array}$ & Sm-Nd & $\begin{array}{l}\text { WR- } \\
\text { isochron }\end{array}$ & 608 & 38 & $\begin{array}{c}\text { Crystallisation } \\
\text { age }\end{array}$ & $\begin{array}{l}\text { Schmitt et al. } \\
\text { (2008b) }\end{array}$ \\
\hline $\begin{array}{l}\text { Regiao dos Lagos } \\
\text { Complex }\end{array}$ & Orthogneiss & Peró beach & $\mathrm{Ar}-\mathrm{Ar}$ & biotite & 593 & 6 & $\begin{array}{l}\text { Metamorphic } \\
\text { age }\end{array}$ & $\begin{array}{c}\text { Fonseca A.C. } \\
\text { (1993) }\end{array}$ \\
\hline $\begin{array}{l}\text { Regiao dos Lagos } \\
\text { Complex }\end{array}$ & Orthogneiss & $\begin{array}{l}\text { São Pedro } \\
\text { D’Aldeia }\end{array}$ & $\mathrm{K}-\mathrm{Ar}$ & amphibole & 571 & 44 & $\begin{array}{c}\text { Metamorphic } \\
\text { age }\end{array}$ & $\begin{array}{c}\text { Zimbres et al. } \\
\text { (1990) }\end{array}$ \\
\hline
\end{tabular}


Appendix I. Continuation.

\begin{tabular}{|c|c|c|c|c|c|c|c|c|}
\hline Geological Unit & Lithotype & Location & Method & Technique & $\begin{array}{l}\text { Age } \\
(\mathrm{Ma})\end{array}$ & Error & Interpretation & Reference \\
\hline $\begin{array}{l}\text { Regiao dos Lagos } \\
\text { Complex }\end{array}$ & $\begin{array}{c}\text { Mafic enclave in } \\
\text { orthogneiss }\end{array}$ & $\begin{array}{c}\text { Conchas beach - } \\
\text { Cabo Frio }\end{array}$ & $\mathrm{Ar}-\mathrm{Ar}$ & hornblend & 570 & 6 & $\begin{array}{l}\text { Metamorphic } \\
\text { age }\end{array}$ & $\begin{array}{c}\text { Fonseca A.C. } \\
\text { (1993) }\end{array}$ \\
\hline Buzios Succession & Orthoamphibolite & $\begin{array}{c}\text { Forte de São } \\
\text { Mateus, Cabo } \\
\text { Frio }\end{array}$ & $\mathrm{U}-\mathrm{Pb}$ & $\begin{array}{l}\text { TIMS(UI) } \\
\text { sphene }\end{array}$ & 551 & 10 & $\begin{array}{l}\text { Metamorphic } \\
\text { age }\end{array}$ & $\begin{array}{l}\text { Schmitt et al. } \\
\qquad(2004)\end{array}$ \\
\hline Buzios Succession & Paragneiss & $\begin{array}{l}\text { Foca Beach } \\
\text { (Buzios) }\end{array}$ & $\mathrm{U}-\mathrm{Pb}$ & ICPMS & 543 & 8 & $\begin{array}{l}\text { Metamorphic } \\
\text { age }\end{array}$ & $\begin{array}{l}\text { Fernandes } \\
\text { et al. (2015) }\end{array}$ \\
\hline $\begin{array}{l}\text { Regiao dos Lagos } \\
\text { Complex }\end{array}$ & Orthogneiss & $\begin{array}{l}\text { Forte de São } \\
\text { Mateus, Cabo } \\
\text { Frio }\end{array}$ & $\mathrm{Ar}-\mathrm{Ar}$ & hornblend & 542 & 6 & $\begin{array}{l}\text { Metamorphic } \\
\text { age }\end{array}$ & $\begin{array}{l}\text { Fonseca A.C. } \\
\text { (1993) }\end{array}$ \\
\hline $\begin{array}{l}\text { José Gonçalves } \\
\text { Suite }\end{array}$ & Orthoamphibolite & $\begin{array}{l}\text { Forte de São } \\
\text { Mateus, Cabo } \\
\text { Frio }\end{array}$ & $\mathrm{Ar}-\mathrm{Ar}$ & hornblend & 537 & 6 & $\begin{array}{l}\text { Metamorphic } \\
\text { age }\end{array}$ & $\begin{array}{c}\text { Fonseca A.C. } \\
\text { (1993) }\end{array}$ \\
\hline Buzios Succession & Paragneiss & $\begin{array}{l}\text { Foca Beach } \\
\text { (Buzios) }\end{array}$ & $\mathrm{U}-\mathrm{Pb}$ & ICPMS & 537 & 4 & $\begin{array}{c}\text { Metamorphic } \\
\text { age }\end{array}$ & $\begin{array}{l}\text { Fernandes } \\
\text { et al. (2015) }\end{array}$ \\
\hline Buzios Succession & Paragneiss & $\begin{array}{l}\text { Foca Beach } \\
\text { (Buzios) }\end{array}$ & $\mathrm{U}-\mathrm{Pb}$ & ICPMS & 533 & 4 & $\begin{array}{l}\text { Metamorphic } \\
\text { age }\end{array}$ & $\begin{array}{l}\text { Fernandes } \\
\text { et al. (2015) }\end{array}$ \\
\hline $\begin{array}{l}\text { Regiao dos Lagos } \\
\text { Complex }\end{array}$ & Orthogneiss & Rio das Ostras & $\mathrm{U}-\mathrm{Pb}$ & TIMS (LI) & 525 & 37 & $\begin{array}{l}\text { Metamorphic } \\
\text { age }\end{array}$ & $\begin{array}{l}\text { Schmitt et al. } \\
\qquad(2004)\end{array}$ \\
\hline Buzios Succession & Leucosome & $\begin{array}{l}\text { Foca Beach } \\
\text { (Buzios) }\end{array}$ & $\mathrm{U}-\mathrm{Pb}$ & TIMS (UI) & 525 & 9 & $\begin{array}{l}\text { Metamorphic } \\
\text { age }\end{array}$ & $\begin{array}{l}\text { Schmitt et al. } \\
\qquad(2004)\end{array}$ \\
\hline Palmital Succession & Paragneiss & Ponta Negra & $\mathrm{U}-\mathrm{Pb}$ & SHRIMP & 523,8 & 12,3 & $\begin{array}{l}\text { Metamorphic } \\
\text { age }\end{array}$ & $\begin{array}{l}\text { Schmitt et al. } \\
\qquad(2004)\end{array}$ \\
\hline Buzios Succession & Paragneiss & $\begin{array}{l}\text { Foca Beach } \\
\text { (Buzios) }\end{array}$ & $\mathrm{U}-\mathrm{Pb}$ & ICPMS & 522 & 4 & $\begin{array}{l}\text { Metamorphic } \\
\text { age }\end{array}$ & $\begin{array}{l}\text { Fernandes } \\
\text { et al. (2015) }\end{array}$ \\
\hline Buzios Succession & Orthoamphibolite & $\begin{array}{c}\text { Forte de São } \\
\text { Mateus, Cabo } \\
\text { Frio }\end{array}$ & $\mathrm{U}-\mathrm{Pb}$ & TIMS (LI) & 519 & 19 & $\begin{array}{l}\text { Metamorphic } \\
\text { age }\end{array}$ & $\begin{array}{l}\text { Schmitt et al. } \\
\qquad(2004)\end{array}$ \\
\hline $\begin{array}{l}\text { Regiao dos Lagos } \\
\text { Complex }\end{array}$ & Orthogneiss & Rio das Ostras & $\mathrm{U}-\mathrm{Pb}$ & TIMS (LI) & 519 & 11 & $\begin{array}{l}\text { Metamorphic } \\
\text { age }\end{array}$ & $\begin{array}{l}\text { Schmitt et al. } \\
\qquad(2004)\end{array}$ \\
\hline $\begin{array}{l}\text { Regiao dos Lagos } \\
\text { Complex }\end{array}$ & Leucosome & Rio das Ostras & $\mathrm{U}-\mathrm{Pb}$ & TIMS (UI) & 518 & 5 & $\begin{array}{l}\text { Metamorphic } \\
\text { age }\end{array}$ & $\begin{array}{l}\text { Schmitt et al. } \\
\qquad(2004)\end{array}$ \\
\hline Buzios Succession & Paragneiss & $\begin{array}{c}\text { Foca Beach } \\
\text { (Buzios) }\end{array}$ & $\mathrm{U}-\mathrm{Pb}$ & ICPMS & 517 & 4 & $\begin{array}{l}\text { Metamorphic } \\
\text { age }\end{array}$ & $\begin{array}{l}\text { Fernandes } \\
\text { et al. (2015) }\end{array}$ \\
\hline Buzios Succession & Paragneiss & $\begin{array}{l}\text { Foca Beach } \\
\text { (Buzios) }\end{array}$ & $\mathrm{U}-\mathrm{Pb}$ & ICPMS & 517 & 3 & $\begin{array}{l}\text { Metamorphic } \\
\text { age }\end{array}$ & $\begin{array}{l}\text { Fernandes } \\
\text { et al. (2015) }\end{array}$ \\
\hline Buzios Succession & Paragneiss & $\begin{array}{l}\text { Tartaruga Beach } \\
\text { (Buzios) }\end{array}$ & $\mathrm{U}-\mathrm{Pb}$ & $\begin{array}{l}\text { TIMS(UI) } \\
\text { monazite }\end{array}$ & 513 & 2 & $\begin{array}{l}\text { Metamorphic } \\
\text { age }\end{array}$ & $\begin{array}{l}\text { Schmitt et al. } \\
\qquad(2004)\end{array}$ \\
\hline Buzios Succession & Paragneiss & $\begin{array}{l}\text { Foca Beach } \\
\text { (Buzios) }\end{array}$ & $\mathrm{U}-\mathrm{Pb}$ & $\begin{array}{l}\text { TIMS(UI) } \\
\text { monazite }\end{array}$ & 511 & 2 & $\begin{array}{l}\text { Metamorphic } \\
\text { age }\end{array}$ & $\begin{array}{l}\text { Schmitt et al. } \\
\qquad(2004)\end{array}$ \\
\hline Buzios Succession & Orthoamphibolite & $\begin{array}{l}\text { Geribá beach } \\
\text { (Buzios) }\end{array}$ & $\mathrm{U}-\mathrm{Pb}$ & $\begin{array}{l}\text { TIMS(UI) } \\
\text { sphene }\end{array}$ & 510 & 5 & $\begin{array}{l}\text { Metamorphic } \\
\text { age }\end{array}$ & $\begin{array}{l}\text { Schmitt et al. } \\
\qquad(2004)\end{array}$ \\
\hline Buzios Succession & Paragneiss & $\begin{array}{c}\text { Foca Beach } \\
\text { (Buzios) }\end{array}$ & $\mathrm{U}-\mathrm{Pb}$ & ICPMS & 510 & 3 & $\begin{array}{l}\text { Metamorphic } \\
\text { age }\end{array}$ & $\begin{array}{l}\text { Fernandes } \\
\text { et al. (2015) }\end{array}$ \\
\hline Buzios Succession & Paragneiss & $\begin{array}{l}\text { Foca Beach } \\
\text { (Buzios) }\end{array}$ & $\mathrm{U}-\mathrm{Pb}$ & ICPMS & 509 & 4 & $\begin{array}{l}\text { Metamorphic } \\
\text { age }\end{array}$ & $\begin{array}{l}\text { Fernandes } \\
\text { et al. (2015) }\end{array}$ \\
\hline
\end{tabular}


Appendix I. Continuation.

\begin{tabular}{|c|c|c|c|c|c|c|c|c|}
\hline Geological Unit & Lithotype & Location & Method & Technique & $\begin{array}{l}\text { Age } \\
\text { (Ma) }\end{array}$ & Error & Interpretation & Reference \\
\hline Buzios Succession & Paragneiss & $\begin{array}{l}\text { Foca Beach } \\
\text { (Buzios) }\end{array}$ & $\mathrm{U}-\mathrm{Pb}$ & ICPMS & 509 & 8 & $\begin{array}{l}\text { Metamorphic } \\
\text { age }\end{array}$ & $\begin{array}{l}\text { Fernandes } \\
\text { et al. (2015) }\end{array}$ \\
\hline $\begin{array}{l}\text { Regiao dos Lagos } \\
\text { Complex }\end{array}$ & Orthogneiss & $\begin{array}{l}\text { Forte de São } \\
\text { Mateus, Cabo } \\
\text { Frio }\end{array}$ & $\mathrm{Ar}-\mathrm{Ar}$ & biotite & 507 & 6 & $\begin{array}{l}\text { Metamorphic } \\
\text { age }\end{array}$ & $\begin{array}{c}\text { Fonseca A.C. } \\
(1993)\end{array}$ \\
\hline Palmital Succession & Paragneiss & Ponta Negra & $\mathrm{U}-\mathrm{Pb}$ & $\begin{array}{l}\text { TIMS(UI) } \\
\text { monazite }\end{array}$ & 505 & 2 & $\begin{array}{l}\text { Metamorphic } \\
\text { age }\end{array}$ & $\begin{array}{c}\text { Schmitt et al. } \\
\text { (2004) }\end{array}$ \\
\hline Palmital Succession & Paragneiss & Ponta Negra & $\mathrm{U}-\mathrm{Pb}$ & TIMS(UI) & 504 & 21 & $\begin{array}{l}\text { Metamorphic } \\
\text { age }\end{array}$ & $\begin{array}{c}\text { Schmitt et al. } \\
\text { (2004) }\end{array}$ \\
\hline Silva Jardim pluton & Granite & Silva Jardim & $\mathrm{U}-\mathrm{Pb}$ & ICPMS & 505 & 2 & $\begin{array}{c}\text { Crystallisation } \\
\text { age }\end{array}$ & $\begin{array}{l}\text { Moraes } \\
(2009)\end{array}$ \\
\hline $\begin{array}{l}\text { Regiao dos Lagos } \\
\text { Complex }\end{array}$ & Orthogneiss & $\begin{array}{l}\text { Conchas beach - } \\
\text { Cabo Frio }\end{array}$ & $\mathrm{U}-\mathrm{Pb}$ & TIMS (LI) & 501 & 6 & $\begin{array}{c}\text { Metamorphic } \\
\text { age }\end{array}$ & $\begin{array}{c}\text { Schmitt et al. } \\
\text { (2008b) }\end{array}$ \\
\hline Buzios Succession & Orthoamphibolite & $\begin{array}{l}\text { Geribá beach } \\
\text { (Buzios) }\end{array}$ & $\mathrm{U}-\mathrm{Pb}$ & TIMS(LI) & 497 & 6 & $\begin{array}{l}\text { Metamorphic } \\
\text { age }\end{array}$ & $\begin{array}{c}\text { Schmitt et al. } \\
\text { (2004) }\end{array}$ \\
\hline Palmital Succession & Paragneiss & Ponta Negra & $\mathrm{U}-\mathrm{Pb}$ & $\begin{array}{l}\text { TIMS(UI) } \\
\text { monazite }\end{array}$ & 497 & 3 & $\begin{array}{l}\text { Metamorphic } \\
\text { age }\end{array}$ & $\begin{array}{c}\text { Schmitt et al. } \\
\text { (2004) }\end{array}$ \\
\hline Buzios Succession & Paragneiss & $\begin{array}{l}\text { Foca Beach } \\
\text { (Buzios) }\end{array}$ & $\mathrm{U}-\mathrm{Pb}$ & ICPMS & 496 & 4 & $\begin{array}{c}\text { Metamorphic } \\
\text { age }\end{array}$ & $\begin{array}{l}\text { Fernandes } \\
\text { et al. (2015) }\end{array}$ \\
\hline Buzios Succession & Paragneiss & $\begin{array}{l}\text { Lagoinha point } \\
\text { (Buzios) }\end{array}$ & $\mathrm{U}-\mathrm{Pb}$ & $\begin{array}{l}\text { TIMS(UI) } \\
\text { monazite }\end{array}$ & 494 & 4 & $\begin{array}{l}\text { Metamorphic } \\
\text { age }\end{array}$ & $\begin{array}{c}\text { Schmitt et al. } \\
(2004)\end{array}$ \\
\hline $\begin{array}{l}\text { Regiao dos Lagos } \\
\text { Complex }\end{array}$ & Orthogneiss & Araruama & $\mathrm{K}-\mathrm{Ar}$ & biotite & 494 & 11 & Cooling age & $\begin{array}{c}\text { Zimbres et al. } \\
\text { (1990) }\end{array}$ \\
\hline Buzios Succession & Paragneiss & $\begin{array}{l}\text { Foca Beach } \\
\text { (Buzios) }\end{array}$ & $\mathrm{U}-\mathrm{Pb}$ & ICPMS & 489 & 2 & $\begin{array}{l}\text { Metamorphic } \\
\text { age }\end{array}$ & $\begin{array}{l}\text { Fernandes } \\
\text { et al. (2015) }\end{array}$ \\
\hline $\begin{array}{l}\text { Regiao dos Lagos } \\
\text { Complex }\end{array}$ & Orthogneiss & $\begin{array}{l}\text { São Pedro } \\
\text { D’Aldeia }\end{array}$ & $\mathrm{U}-\mathrm{Pb}$ & TIMS (UI) & 488 & 55 & Cooling age & $\begin{array}{c}\text { Zimbres et al. } \\
\text { (1990) }\end{array}$ \\
\hline Palmital Succession & Paragneiss & Ponta Negra & $\mathrm{U}-\mathrm{Pb}$ & SHRIMP & 483,3 & 12 & $\begin{array}{l}\text { Metamorphic } \\
\text { age }\end{array}$ & $\begin{array}{c}\text { Schmitt et al. } \\
(2004)\end{array}$ \\
\hline $\begin{array}{l}\text { Regiao dos Lagos } \\
\text { Complex }\end{array}$ & Orthogneiss & $\begin{array}{l}\text { São Pedro } \\
\text { D’Aldeia }\end{array}$ & $\mathrm{K}-\mathrm{Ar}$ & biotite & 474 & 12 & Cooling age & $\begin{array}{c}\text { Zimbres et al. } \\
\text { (1990) }\end{array}$ \\
\hline $\begin{array}{l}\text { Regiao dos Lagos } \\
\text { Complex }\end{array}$ & Orthogneiss & Macaé city & $\mathrm{U}-\mathrm{Pb}$ & TIMS (LI) & 465 & 52 & Cooling age & $\begin{array}{c}\text { Schmitt et al. } \\
\text { (2004) }\end{array}$ \\
\hline $\begin{array}{l}\text { Regiao dos Lagos } \\
\text { Complex }\end{array}$ & Orthogneiss & $\begin{array}{l}\text { São Pedro } \\
\text { D’Aldeia }\end{array}$ & $\mathrm{K}-\mathrm{Ar}$ & biotite & 460 & 23 & Cooling age & $\begin{array}{l}\text { Delhal et al. } \\
\text { (1969) }\end{array}$ \\
\hline Cajú pluton & $\begin{array}{l}\text { Fine grained } \\
\text { granite }\end{array}$ & Ponta Negra & $\mathrm{U}-\mathrm{Pb}$ & SHRIMP & 454 & 5 & $\begin{array}{l}\text { Crystallisation } \\
\text { age }\end{array}$ & $\begin{array}{l}\text { Bongiolo } \\
\text { et al. (2015) }\end{array}$ \\
\hline Palmital Succession & Leucocratic dyke & Ponta Negra & $\mathrm{U}-\mathrm{Pb}$ & TIMS (UI) & 447 & 20 & Post collision & $\begin{array}{c}\text { Schmitt et al. } \\
\text { (2004) }\end{array}$ \\
\hline $\begin{array}{l}\text { Regiao dos Lagos } \\
\text { Complex }\end{array}$ & Orthogneiss & $\begin{array}{l}\text { São Pedro } \\
\text { D’Aldeia }\end{array}$ & $\mathrm{K}-\mathrm{Ar}$ & muscovite & 434 & 22 & Cooling age & $\begin{array}{l}\text { Delhal et al. } \\
\text { (1969) }\end{array}$ \\
\hline
\end{tabular}

